\title{
Human Impacts on a Small Island Ecosystem: Lessons from the Lucayans of San Salvador, Bahamas for This Island Earth
}

\author{
Jeffrey P. Blick \\ Georgia College and State University
}

USA

\section{Introduction}

The issues of prehistoric impact on the environment, resource overexploitation, and overfishing have emerged as major themes over the last few decades as scholars have come to realize that indigenous peoples, even those living at relatively simple levels of technology, such as land-based hunter-gatherers and "maritime hunter-gatherers" (Yesner, 1980), appear to have had the capability of significantly altering their local and regional environments by reducing biodiversity through customary subsistence practices such as horticulture, hunting, shellfish collecting, and fishing (Keegan, Portell, \& Slapcinsky, 2003; Krech, 1999; Newsom \& Wing, 2004; Redman, 1999; Wing, 1989, 2001; Wing \& Wing 2001). Modern zooarchaeological techniques and accompanying statistical analyses are allowing us to address these important themes by providing quantitative measures of prehistoric human-environmental interaction, but zooarchaeological data must be multivariate (and demonstrate consistent trends), and must be understood within the broader context of human social behavior, modes of prehistoric subsistence, and human adaptation to ancient environments. Multifaceted evidence from numerous zooarchaeological studies across the Greater Caribbean illustrates that the Taíno and related cultures of the Antilles, including the Lucayans of the Bahamas, indeed had significant, wide-reaching, and profound impacts on the terrestrial, intertidal, and marine environments of the Greater and Lesser Antilles and the Bahamian Archipelago (Blick, 2006; Blick \& Murphy, 2005; Carlson, 1999; Carlson \& Keegan, 2004; Keegan, Portell, \& Slapcinsky, 2003; Newsom \& Wing, 2004; Steadman \& Stokes, 2002; Wing, 2001; Wing, deFrance, \& Kozuch, 2002; Wing \& Wing, 2001). In fact, prehistoric impact on the environment appears to be one of the main emerging themes of island and coastal archaeology, particularly in the Caribbean, of the last three decades or so (Erlandson \& Fitzpatrick, 2006; Newsom \& Wing, 2004; Wing, 1989; Wing \& Reitz, 1982; Wing \& Scudder, 1983).

The issues of marine resource exploitation and fishing pressure, sometimes referred to as overfishing, appear to have reached a critical mass in the scientific literature in recent years (Baum et al., 2003; Coleman et al., 2004; Conover \& Munch, 2002; Hawkins \& Roberts, 2004; Jackson et al., 2001; Mumby et al., 2006; Pandolfi et al., 2003; Pauly et al., 1998; Sibert et al., 2006; Worm et al., 2006). Recreational, artisanal, and industrial fishing pressures on coastal 
and marine ecosystems clearly have implications for the conservation, establishment, and management of modern no-take reserves and marine protected areas. Based upon an examination of the scientific literature, characteristics of overfishing include: targeting and depletion of apex predators (Baum et al., 2003; Estes, et al., 2011; Frank, et al., 2005; Hawkins \& Roberts, 2004; Jackson et al., 2001) such as sharks, groupers, snappers, jacks, and larger individuals (Conover \& Munch, 2002; Hawkins \& Roberts, 2004; Pandolfi et al., 2003; Pauly et al., 1998; Sibert et al., 2006); truncated or decreasing size and age distributions of targeted species ("growth overfishing") (Coleman et al., 2004; Conover \& Munch, 2002; Pauly et al., 1998); genetic changes in somatic growth rates (Conover \& Much, 2002); declining fisheries biomass (Hawkins \& Roberts, 2004; Sibert, 2006); altered community composition or functioning (Bjorndal \& Jackson, 2003; Coleman et al., 2004; Estes, et al., 2011; Frank, et al., 2005; Hawkins \& Roberts, 2004; Jackson et al., 2001; Mumby et al., 2006; Worm et al., 2006); decline in the mean trophic level of fisheries landings (Pauly et al., 1998); reduction of biodiversity (Jackson et al., 2001; Pandolfi et al., 2003; Worm et al., 2006); and regional extirpations or global extinctions (Hawkins \& Roberts, 2004; Jackson et al., 2001; Pandolfi et al., 2003). Several of these phenomena are observable in the data presented in this chapter (see also Blick, 2006; 2007; Blick \& Kjellmark, 2006).

Regarding human impact on coastal and marine ecosystems, the good news appears to be that current rates of overfishing are reversible, at least on local and regional scales (Myers et al., 1995; Worm et al., 2006), and biologists are now aware of the pitfalls of focusing on only one key species (Baum et al., 2003) or substrate (e.g., sea grasses, reefs) (Mumby et al., 2006) for conservation purposes. The bad news is that "humans have been disturbing marine ecosystems since they first learned how to fish" (Jackson et al., 2001:629) and that "Changes in ecosystem structure and function occurred as early as the late aboriginal [stage]" (Jackson et al., 2001:636) and will likely continue unabated into the near future when global fisheries are projected to collapse by ca. A.D. 2050 (Pauly et al., 1998; Worm et al., 2006). Finally, the question of whether or not the pre-Columbian Lucayans of San Salvador practiced "sustainable" harvesting of coastal and marine organisms will be addressed. The answer to this question has serious implications for the concept of ecological sustainability in conservation circles and has grave implications regarding human population size, resource use, and environmental impacts in the future.

The main purpose of this chapter is to present new data from the archaeological record of the island of San Salvador, Bahamas, on the nature of prehistoric impact on the environment and to examine the nature of pre-Columbian resource overexploitation and overfishing. The findings derive from two roughly contemporaneous archaeological sites, Minnis-Ward (SS-3) and North Storr's Lake (SS-4), located on opposite sides of San Salvador with somewhat different ecological and archaeological characteristics (see Background, below). Remains of key invertebrate and vertebrate fauna are used to illustrate significant trends of decline in abundance and size of prehistoric subsistence items, several of which were highly ranked or preferential food resources of the Lucayan Indians of the Bahamas (see Keegan, 1992:132, Table 6.1). Even though the pre-Columbian population of the island was relatively minor, the evidence presented herein indicates that the Lucayan population of San Salvador had significant environmental impacts on the terrestrial, intertidal, and marine environments of this small island ecosystem. 
Human Impacts on a Small Island Ecosystem:

Lessons from the Lucayans of San Salvador, Bahamas for This Island Earth

\section{Background}

\subsection{The study area: San Salvador Island, Bahamas}

San Salvador Island is one of some 700 islands in the Commonwealth of the Bahamas

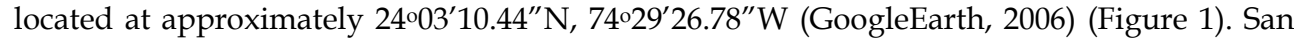
Salvador is best known as the leading contender for the site of the historic Columbus landfall in October of 1492 (Long Bay Site, SS-9, white triangle in Figure 2; Blick, 2011a; Brill \& Hoffman, 1985; Brill et al., 1987; Hoffman, 1987; Keegan, 1992; Obregón, 1987, 1989). Prior to Columbus's arrival that fateful year, San Salvador and the rest of the Bahamian Archipelago had been occupied since about A.D. 600 by a prehistoric Arawakan-speaking people known as the Lucayans, the "island people" of the Bahamas (Albury, 1975; Berman \& Gnivecki, 1995; Granberry \& Vescelius, 2004; Keegan, 1992).

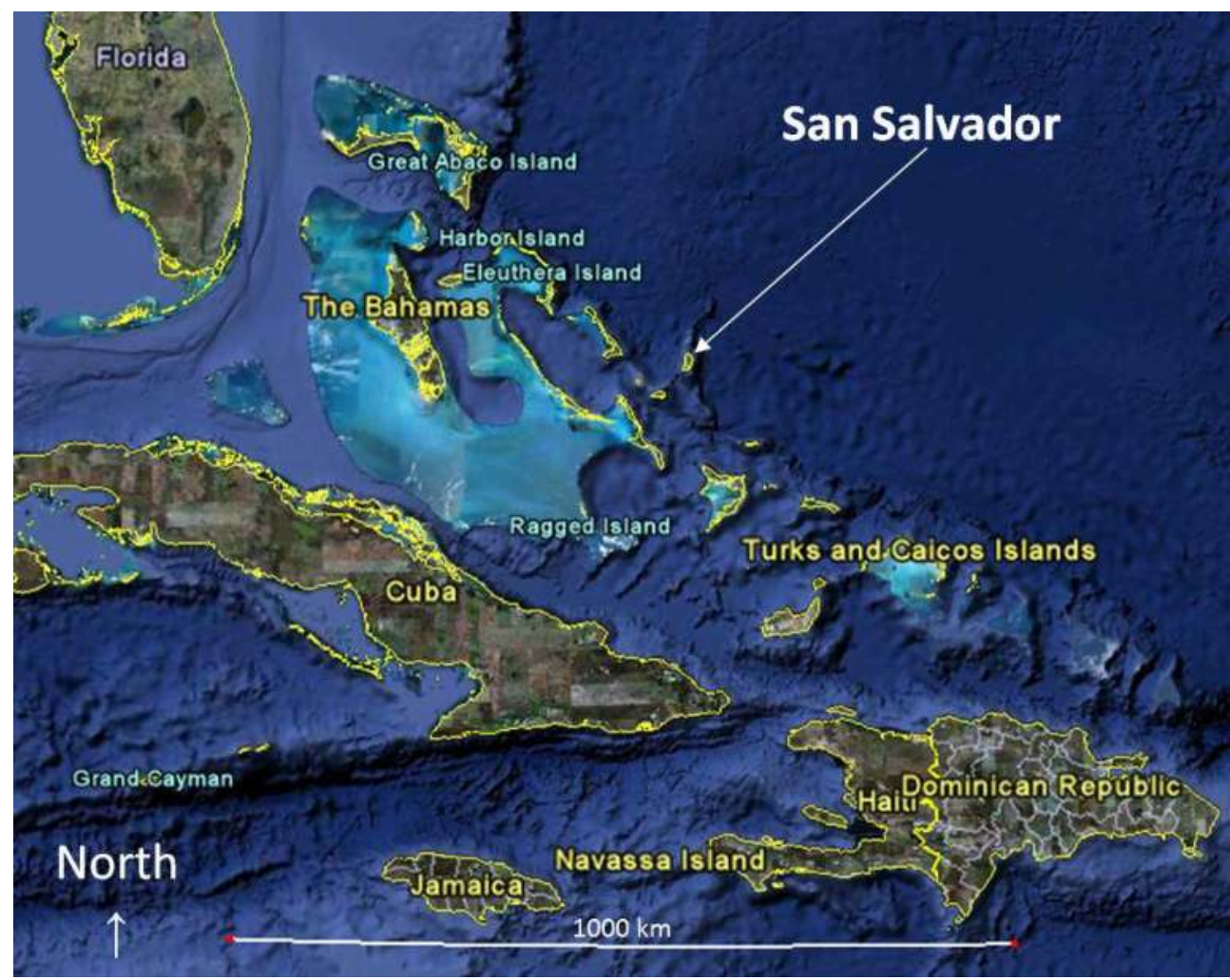

Fig. 1. Map of the Commonwealth of the Bahamas. San Salvador is located at approximately $24^{\circ} \mathrm{N} 74^{\circ} 30^{\prime} \mathrm{W}$ in the central eastern Bahamas. Scale is $1000 \mathrm{~km}$ (622 miles).

The Lucayans were a seafaring, fishing, and horticultural society with origins ultimately on the South American mainland (Rouse, 1992; S. Wilson, 1999). They were master dugout canoe makers and wood carvers (Albury, 1975; Berman, 1999) and they traded with cultures as far away as Central and South America (Johnson, 1980). Lucayan subsistence was based on a mixed economy of fishing in the semi-tropical waters of their islands and on 
horticulture of such plants as manioc, cocoyam, maize, other starchy vegetables, gourds or squashes, chili peppers, fruits, cotton, tobacco, etc. (Berman \& Pearsall, 2000, 2005, 2008; Keegan, 1992; Perry, et al. 2007). There is substantial plant macrofossil, phytolith, and pollen evidence from San Salvador and Andros Island that indigenous horticultural practices altered the terrestrial landscapes of the islands of the Bahamas during the pre-Columbian period (Berman \& Pearsall, 2000; Blick \& Kjellmark, 2006; Kjellmark, 1996).

Some of the earliest evidence for human occupation in the Bahamas comes from San Salvador (Berman \& Gnivecki, 1995). Dated to about A.D. 600, these peoples had ceramic ties with nearby islands of the Greater Antilles such as Cuba and Hispaniola (Berman \& Gnivecki, 1995; Granberry \& Vescelius, 2004; Hoffman, 1967; Winter \& Gilstrap, 1991). Over the ca. 900 years of occupation on the island of San Salvador, the Lucayans founded, and thrived at, some 40 prehistoric sites across the island (Blick, Hopkins, \& Oetter, 2011; Hopkins, Oetter, \& Blick, 2011), most of which were located on dune ridges near the coastline and the ocean resources they had come to rely upon for their sustenance (Keegan, 1997).

This study is based upon archaeological work performed at two sites on San Salvador, the Minnis-Ward site (SS-3) and the North Storr's Lake site (SS-4) (Figure 2). Generally speaking, these two sites are roughly contemporaneous, located on opposite sides of the island, and have somewhat different ecological and archaeological characteristics. Calibrated radiocarbon dates from Minnis-Ward span the period ca. A.D. 880-1490 (2-sigma) (Blick \& Dvoracek 2011; Blick, Creighton, \& Murphy 2006; Winter, 1981, 1997) while calibrated pre-Columbian dates from North Storr's Lake range from ca. A.D. 860-1520 (2sigma) (Blick \& Dvoracek, 2011; Blick, Creighton, \& Murphy 2006; Delvaux, Fry, \& Murphy, 2006; Shaklee, Fry, \& Delvaux 2007). The Minnis-Ward site is a linear village on a dune ridge located on the western or leeward side of San Salvador near a patch reef complex and is situated about $200 \mathrm{~m}$ from the ocean. North Storr's Lake is also a linear village on a dune ridge and adjacent lakeshore on the eastern or windward side of the island about $180 \mathrm{~m}$ from the ocean near a linear fringing reef. Archaeological deposits differ, with Minnis-Ward characterized by a high density midden with abundant Scaridae (parrotfishes), moderate amounts of Cheloniidae (sea turtle), and a few high status artifacts including imported pottery, an imported sandstone tablet, a rock crystal, and a serpentine cohoba (Anadenanthera peregrina) hallucinogenic snuff grinder (Blick, et al., 2009). North Storr's Lake appears to have a medium-to-high density midden with abundant Serranidae (grouper) and Cheloniidae (Blick \& Murphy, 2005; Blick, Creighton, \& Murphy, 2006), and several likely high status artifacts including copper fragments, greenstone nodules, a quartz crystal, a petaloid ax (Delvaux, Fry, \& Murphy, 2006), and an incised shell inlay fragment for a wooden pre-Columbian idol known as a zemi ("spirit figure") (Blick, Creighton, \& Murphy, 2006:29, Fig. 23a).

More specifically, the Minnis-Ward site is located on the northwest corner of San Salvador Island, approximately $1 \mathrm{~km}$ south of Rocky Point some $200 \mathrm{~m}$ east (inland) from the ocean and some $100 \mathrm{~m}$ west of Triangle Pond (Figure 2). The site's coordinates are $24{ }^{\circ} 06^{\prime} 2.22^{\prime \prime} \mathrm{N}$, 74.31'5.5”W (Winter, 1997). Dimensions of the site are approximately $100 \times 100 \mathrm{~m}$, covering an elongated elliptical area of ca. $8400 \mathrm{~m}^{2}$ (Winter, 1997) along a southwest-northeast trending dune ridge. The Minnis-Ward site (aka Ward site, Ward/Minnis site, etc.) was first reported by Ruth Wolper in the late 1950s and tested by John Goggin in 1960 (Hoffman, 1967; Winter, 1997). Testing and excavations by John Winter $(1980,1981,1997)$ have yielded 
large quantities of vertebrate and invertebrate faunal remains (Winter \& Wing, 1995) dominated by Scaridae and Serranidae, including relatively abundant quantities of Cheloniidae, some of which have been identified to the species Caretta caretta (Linnaeus, 1758) (loggerhead turtle) (Winter, 1980, 1981). Prehistoric radiocarbon dates reported by Winter $(1981,1997)$ and Blick, Creighton, \& Murphy (2006; see also Blick \& Dvoracek, 2011) span the period ca. A.D. 880-1490 (calibrated, 2-sigma). Winter (1980:3) also reports three post molds (impressions of posts) in the "yellow-white coral sand" of the site at about 51-53 $\mathrm{cm}$ below the surface, perhaps indicative of a pre-Columbian structure at the site. Blick's (2003) preliminary shovel testing program at the site also revealed evidence for the presence of multiple prehistoric houses at the site based on the spatial distribution of artifacts recovered in shovel tests. Winter (1981:5) classifies the site as an "open village site," an interpretation supported by Blick $(2003,2004)$. The archaeological materials from Minnis-Ward discussed in this chapter derive from Blick's May 2004 excavation of a $5 \times 5 \mathrm{~m}$ unit in a high density area of artifacts near a pre-Columbian structure designated as Household 1 (Blick, 2004). Additional work at Minnis-Ward, now a threatened site, continued in 2009 and 2010.

The North Storr's Lake site (SS-4) is a prehistoric Lucayan archaeological site located on the northeastern side of the island of San Salvador (Figure 2) contained within an area of approximately 300 meters north-south by $150 \mathrm{~m}$ east-west between the northeast shoreline of northern Storr's Lake and the east facing foredune paralleling the Atlantic Ocean. Based on current data available from GoogleEarth (2006), the coordinates of the approximate center of the site are $24^{\circ} 05^{\prime} 00.00^{\prime \prime} \mathrm{N}, 74^{\circ} 26^{\prime} 19.00^{\prime \prime} \mathrm{W}$. Like many of the archaeological sites on San Salvador, the North Storr's Lake site was discovered in the early 1980s by John Winter (Winter, 1981, 1982). Winter (1981) reports that he excavated six test pits at the North Storr's Lake site and recovered prehistoric Lucayan Palmetto Ware pottery from two of the six test pits. "The two pits which produced sherds are located in that region of the lake which is covered with swamp vegetation" (Winter, 1981:7). Also according to Winter (1982:8), in January 1982, "five test pits were dug at the Storrs Lake Site ... in order to better evaluate the size and nature of the site." Although a portion of the site appears to have been disturbed at that time by cultivation and bulldozer operations, "cultural material came from a depth of between 29-35 cm" (Winter, 1982:8). At the time of the 1982 investigation, Winter reported the dimensions of the site to be approximately $111 \mathrm{~m}$ long by $56 \mathrm{~m}$ wide. According to Winter (1982:8), "Since parts of the site seem undisturbed, and since it is larger than many other sites presently known in the Bahamas, excavation in the future may be warranted." As far as the author's knowledge is concerned, the North Storr's Lake site subsequently lay untouched by archaeologists until 1996 when Dr. Gary Fry of Youngstown State University (YSU) began a multi-year project that lasted until 2001. Previous work performed under the auspices of YSU under the supervision of Dr. Gary Fry and Tom Delvaux has been recently described by Delvaux, Fry, \& Murphy (2006) and Shaklee, Fry, \& Delvaux (2007). Radiocarbon dates reported by Shaklee, Fry, \& Delvaux (2007:34, Table 1) for the North Storr's Lake site span the time range ca. A.D. 860-1650 (calibration not reported; the later date is most probably non-Lucayan) with new prehistoric dates reported by Blick, Creighton, \& Murphy (2006) and Blick \& Dvoracek (2011) on a different portion of the site covering the period ca. A.D. 1300-1520 (calibrated, 2-sigma). The archaeological materials from North Storr's Lake discussed in this chapter derive from Blick's May 2005 $2 \times 2 \mathrm{~m}$ excavation in a high density household midden area (Blick \& Murphy, 2005) associated with abundant fish remains and the latter radiocarbon dates. 


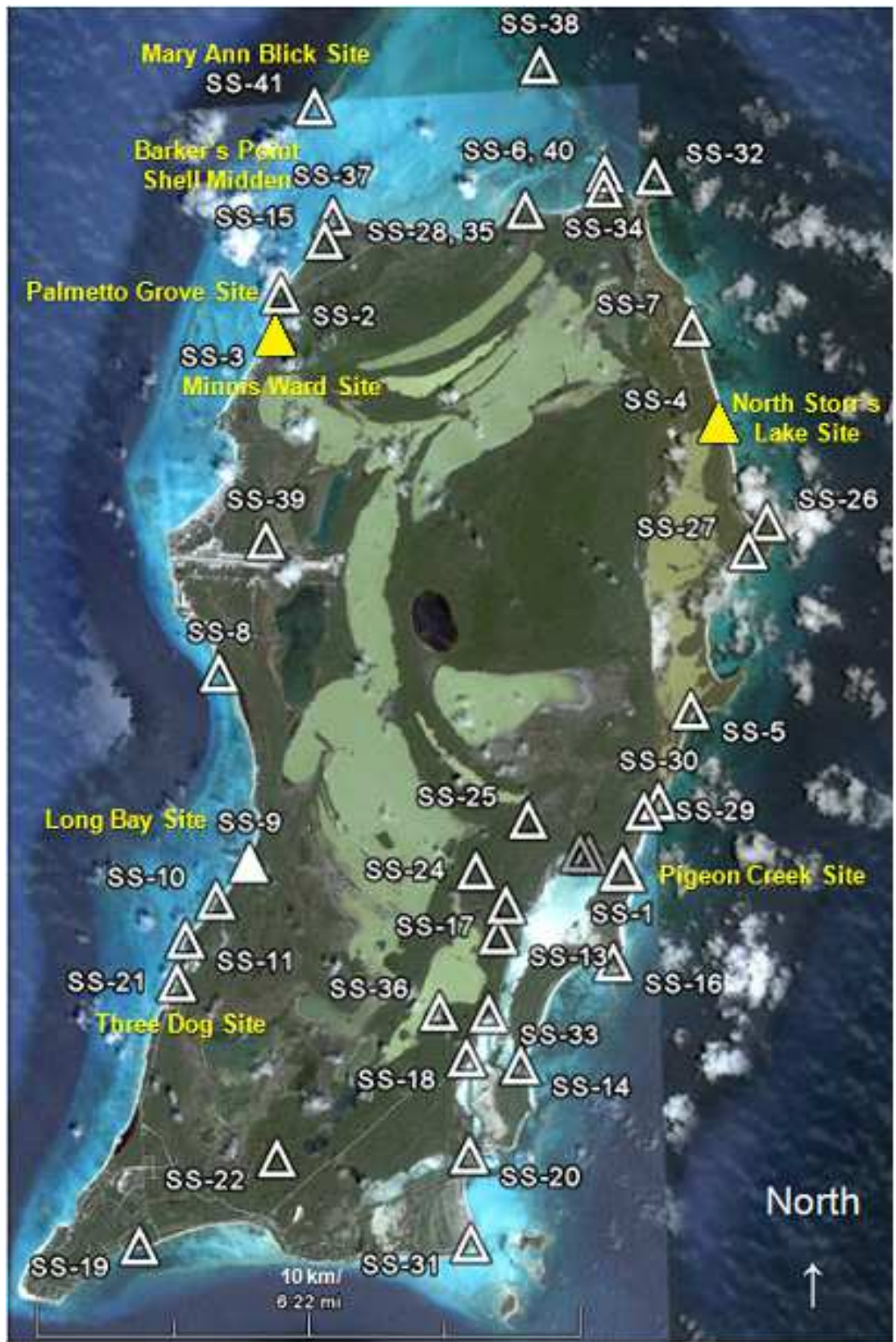

Fig. 2. Map of the island of San Salvador, Bahamas showing the locations of the MinnisWard site (SS-3) (NW corner of the island) and the North Storr's Lake site (SS-4) (NE corner of the island) (sites indicated by yellow triangles). Scale is $10 \mathrm{~km}$ (6.22 miles). The Long Bay site (SS-9) (white triangle) is the probable site of the 1492 Columbus landfall (Blick, 2011a). 


\subsection{Pre-Columbian resource overexploitation in the Greater Caribbean and Bahamas}

Over approximately the last three decades, zooarchaeologists working in the Greater Caribbean and Bahamas have recorded numerous archaeological sites where quantities and sizes of crab, mollusks, and fishes have declined over time from earlier to later deposits. One of the first cases in which such a trend was noticed was the decline in abundance of Gecarcinidae (land crab) remains on Puerto Rico by Rainey (1940) which he interpreted as the transition from a "crab culture" to a "shell culture," suggesting two different cultural groups with varying subsistence strategies. Rainey's model has since been shown to be incorrect since pottery styles (thought to be indicative of different cultures or migrations) did not change during this transition (Goodwin, 1980; Rouse, 1992). Various explanations have been put forth to explain this shift from an abundance of crab in earlier cultural periods to a greater reliance on mollusks in later cultural periods, including depletion of crab by human predators, climate change, and alteration of the terrestrial landscape by habitat-destroying human agricultural practices (Jones, 1985; Carlson \& Keegan, 2004). The declines in abundance and size of Gecarcinidae have since been noticed on many Caribbean islands such as Antigua, Nevis, Puerto Rico, Saba, St. John, St. Martin, St. Thomas, etc. (Jones, 1985; Quitmyer, 2003; Wing, 2001; Wing, deFrance, \& Kozuch, 2002), and is today recognized as a widespread phenomenon in the archaeological record of the Caribbean (Serrand, 2002). The most common explanation for this widespread pattern of decline in Gecarcinidae remains is overexploitation by human collectors (see also LaPilusa \& Heilveil, 2011).

Mollusks, such as Cittarium pica (Linnaeus, 1758) (West Indian top shell), Strombus gigas (Linnaeus, 1758) (queen conch), etc., are also reported to exhibit changes in frequencies and sizes over time in the archaeological record of the Caribbean on such islands as Jamaica, Nevis, St. John, St. Thomas, and others (Keegan, Portell, \& Slapcinsky, 2003; Quitmyer, 2003; Wing, 2001; Wing, deFrance, \& Kozuch, 2002). A preliminary field study by Blick (unpublished data) of $S$. gigas indicates total length of the body of the queen conch was significantly longer on specimens from pre-Columbian middens (e.g., Barker's Point Shell Midden, SS-37) and shorter on specimens from modern conch middens (e.g., modern conchs along the western side of Dump Point site, SS-28/35). Some scholars have suggested that as crab becomes scarce, pre-Columbian shellfish gatherers switch to other protein sources to make up for the lack of others (e.g., Wing, 2001). Keegan (1992), on the other hand, lists $S$. gigas and C. pica as high ranking food resources which would have been targeted first due to their desirable protein and calorie yields, while low value species such as chitons "should have been among the last items added to the diet" (Keegan,1992:130). Chitons, such as Chiton tuberculatus (Linnaeus, 1758) (common West Indian chiton) and Acanthopleura granulata (Gmelin, 1791) (fuzzy chiton), appear to be poorly studied and under-reported in the archaeological literature of the Caribbean (see for example Keegan, 1992; Newsom \& Wing, 2004), so their inclusion in this chapter may motivate others to look more carefully at chitons as potential indicators of human overexploitation of the environment. Reported changes in frequencies and sizes of mollusks from earlier to later deposits, to local disappearance of the resource, are generally taken to reflect stress and intensive exploitation as a result of human predation leading to overfishing and eventual local extirpations (Keegan, Portell, \& Slapcinsky, 2003; Newsom \& Wing, 2004; Wing, 2001; Wing, deFrance, \& Kozuch, 2002). 
Perhaps the most significant finding to have emerged from Caribbean archaeology in recent decades is the recognition of several trends of decreasing abundance and size of various fishes and changing composition of tropical fish communities, especially notable among reef dwellers and coral reef communities. Islands where such studies have been performed include Antigua, Grand Turk, Haiti, Jamaica, Nevis, Puerto Rico, Saba, St. Martin, and St. Thomas, among others (Carlson \& Keegan, 2004; Jones, 1985; Wing, 2001; Wing, deFrance, \& Kozuch, 2002; Wing \& Wing, 2001). These studies show clear and convincing evidence of decreasing abundance of a variety of types of fishes, decreasing size of those fishes as measured by widths of atlases and vertebral centra (which can then be converted to body weights using allometric formulae - see Methods, below), and decline in top predators present in the faunal assemblages with a concomitant increase in herbivores and omnivores (primarily parrotfishes). Only rarely do similar studies show opposing or somewhat different trends (Carder, Reitz, \& Crock, 2007; Whyte, Berman, \& Gnivecki, 2005). The recognition of similarities in these trends between pre-Columbian fisheries and modern global fisheries has major conservation implications regarding fisheries management, sustainability, and human population impact on the environment.

Many of the same studies cited above also demonstrate convincing patterns of decline in the number of taxa identified archaeologically which is taken to represent decline in taxa richness, or biodiversity. In earlier deposits, there are numerically more (and more diverse) taxa than in later archaeological deposits. At the same time, a number of these studies also reports declines in the average trophic levels over time of the total aquatic fauna in the archaeological deposits of various Caribbean islands from the Greater to the Lesser Antilles (Puerto Rico, St. Thomas, St. Martin, Saba, Nevis, etc.) (Newsom \& Wing, 2004; Wing, 2001; Wing, deFrance, \& Kozuch, 2002; Wing \& Wing, 2001). The phenomena mentioned in the paragraphs above are attributed to human-induced resource overexploitation and overfishing of local environments near prehistoric habitation sites.

\section{Methods}

All cultural and faunal remains from the Minnis-Ward and North Storr's Lake sites were collected by the author and students in archaeological sifters or screens using window screen with $1.59 \mathrm{~mm}$ mesh. The archaeological excavation at the Minnis-Ward site (SS-3) was a $5 \times 5 \mathrm{~m}$ excavation located near Household 1 at E10N5 excavated in three levels to a depth of ca. $40 \mathrm{~cm}$ (Blick, 2004). The excavation at North Storr's Lake (SS-4) was a smaller $2 \times 2 \mathrm{~m}$ excavation unit located in an area of household midden deposit at 81E17N which was dug in five levels to a depth of ca. $70 \mathrm{~cm}$ (Blick \& Murphy, 2005). All soils were passed through window screen allowing recovery of very small artifacts such as 1-2 mm shell disc beads, fish vertebrae, and other miniscule bones. This method ensured excellent sampling and collection of small faunal materials that might otherwise be lost. Excavations were conducted within natural sedimentary layers, and excavators attempted to stay within 10 $\mathrm{cm}$ thick arbitrary levels within natural strata. Due to the size of the $5 \times 5 \mathrm{~m}$ excavation at Minnis-Ward, volume of earth excavated was ca. $10.00 \mathrm{~m}^{3}$ yielding 31,408 artifacts and ecofacts; the smaller 2x2 m excavation at North Storr's Lake revealed 11,927 artifacts and ecofacts in ca. $2.80 \mathrm{~m}^{3}$ of earth. Details of the excavations are available in Blick (2004) and Blick \& Murphy (2005). 
Vertebrate and invertebrate faunal materials were identified using the comparative collections at the University of Florida Museum of Natural History (FMNH), Gainesville and the University of Georgia (UGA) Museum of Natural History, Athens and various published guidebooks (see Blick \& Murphy, 2005 for details). Taxonomic nomenclature follows Turgeon, et al., (1998) for invertebrates (mollusks) and Nelson, et al., (2004) for vertebrates (fishes). Zooarchaeological methods employed the techniques developed by Reitz \& Wing (1999), with additional identifications and assistance by Nanny Carder (then conducting research at UGA), Irvy R. Quitmyer (FMNH), and Elizabeth J. Reitz (UGA). Although additional faunal analyses from both sites continue, all efforts were made to identify specimens discussed in this report to the lowest taxonomic level. Faunal material was counted and weighed and recorded on preprinted data recording forms and entered into computer spreadsheets and/or databases for statistical analyses. Because the purpose of these excavations was to investigate changing subsistence patterns and changing exploitation of subsistence resources over time, all key specimens were analyzed, weighed (in g), quantified, measured (in $\mathrm{mm}$ ), and tabulated separately according to their respective archaeological excavation levels. Weights were recorded using an Ohaus Scout Pro SP601 digital scale with $0.1 \mathrm{~g}$ accuracy. Linear measurements were taken on all complete vertebrate specimens presented in this report using a Helios needle nose dial caliper with an accuracy of $0.05 \mathrm{~mm}$. All statistical analyses were performed using SYSTAT ${ }^{\circledR}$ (SPSS Inc., 1997) Version 7.0 and verified with a university statistician. For the purposes of this chapter, only five faunal categories are reported - three invertebrate and two vertebrate taxa - due to sample size and other limitations. The five taxa, the particular variables investigated for each, and other measurements based upon them, are described briefly, below.

Gecarcinidae (land crab) shell fragments, chelipeds and dactyls (claws), etc. were quantified, weighed and tabulated separately for each excavation level of the two archaeological sites. There are two varieties of Gecarcinidae on San Salvador today, Cardisoma guanhumi (Latreille, 1825) (great land crab) and Gecarcinus ruricola (Linnaeus, 1758) (black land crab) (Diehl, et al., 1988). Archaeological specimens of Gecarcinidae are identifiable typically only to the family level (Jones, 1985; Newsom \& Wing, 2004; Wing, 2001; Wing, deFrance, \& Kozuch, 2002) and are notable for their creamy coloration and eggshell-like texture and weight. Modern specimens that retain more life-like colors (gray or maroon, depending on the species) were excluded from analysis. It has been demonstrated throughout archaeological deposits in the West Indies that "land crabs were intensively harvested" (Newsom \& Wing, 2004:196; see also Quitmyer, 2003; Serrand, 2002; Wing, 2001), especially during the Saladoid period (ca. 500 B.C.-A.D. 600). Intensive land crab harvesting was also practiced in later prehistory on San Salvador, as shall later be demonstrated. LaPilusa \& Heilveil (2011) report similarly heavy exploitation of land crabs on modern Andros Island, Bahamas for feasting purposes.

C. pica shell fragments (very few complete specimens were found) were quantified, weighed and tabulated separately for each excavation level. C. pica is readily identifiable by its notable black-and-white coloration and its top-like (or turban-like) shape (Lawson, 1993; Robertson, 2003). Fragmented specimens of C. pica are easily identifiable based on color and sometimes morphology; in the absence of coloration, the shiny whitish-yellow nacre inside the shell may sometimes be used as an additional diagnostic indicator (Blick 
\& Murphy, 2005). C. pica has been called, "the third most important marine invertebrate species eaten by man in the West Indies.... [Today] Its stocks are depleted at many places, large animals having been selectively removed by fishermen and others" (Robertson, 2003; see also Wing, 2001). Depletion of this stock will also be demonstrated for preColumbian San Salvador.

Dorsal plates and dorsal plate fragments of chitons (C. tuberculatas and/or A. granulata) were quantified, weighed and tabulated separately for each excavation level. Chitons are readily identifiable by their eight keeled, overlapping, hinged dorsal plates (Diehl, et al., 1988). Unfortunately, this creature has not been well reported archaeologically (see Keegan, 1992; Newsom \& Wing, 2004), and there is generally no attempt to distinguish the two similar species in the archaeological record (Jones, 1985; Keegan, Portell, \& Slapcinsky, 2003; Newsom \& Wing, 2004). It is said that the dorsal plate of the C. tuberculatus is "heavily keeled" (Diehl, et al., 1988:52) in comparison to that of $A$. granulata. Chitons are considered intertidal creatures that "inhabit rock faces near the high tide line" (Diehl, et al., 1988:52), so their presence inland (away from the rocky swash zone) on an archaeological site is considered to be indicative of human collection, transport, and eventual consumption (Blick, 2003; Keegan, 1992).

Sparisoma viride (Bonnaterre, 1788) (stop light parrotfish) premaxillae, dentaries, and upper and lower pharyngeal grinding mills are readily identifiable in the archaeological record (Reitz \& Wing, 1999:55, Fig. 3.11) and are relatively easy to assign to left or right sides allowing for quick calculation of MNI (minimum number of individuals, the smallest number of individuals necessary to account for all skeletal or other preserved elements of a given species). The lower pharyngeal grinding mill (LPGM) width was taken as a lateral measurement at the greatest medio-lateral breadth (aka greatest width) of the grinding mill from the right posterior edge to the left posterior edge of the grinding plate surface (Blick, 2007; see also Bellwood, 1994:25, Fig. 12; Carder, Reitz, \& Crock, 2007:591, Fig. 3). LPGM length was taken as an antero-posterior measurement from the anterior edge to the posterior edge of the grinding plate surface (Blick, 2007). See Bellwood (1994:25, Fig. 12e) and Reitz \& Wing (1999:55, Fig. 3.11d) for illustrations of the S. viride LPGM (but note that Bellwood and Reitz \& Wing label anterior differently in these diagrams). The technique for taking these measurements was modeled after Reitz's lateral and antero-posterior measurements (personal communication, July 2004). Fragmentary LPGMs were not measured unless at least one of the two measurements was possible. Parrotfishes have been reported as a major subsistence item of the Lucayans on San Salvador (Hoffman, 1967; Whyte, Berman, \& Gnivecki, 2005; Wing, 1969; Winter \& Wing, 1995). The large sample size of $S$. viride LPGMs $(\mathrm{MNI}=249)$ at Minnis-Ward made this bony element particularly amenable to statistical analyses to investigate change over time of one heavily utilized marine (coral reef) resource.

Serranidae (sea bass/grouper) atlases are particularly diagnostic due to the presence of an anterior medial protuberance and dual superior articular facets which articulate with the paired exoccipitals of the basioccipital portion of the neurocranium (Nanny Carder, personal communication, July 2004; Carder, Reitz, \& Crock 2007). The serranids most likely present in and around the waters of San Salvador are the groupers, especially Epinephelus morio (Valenciennes, 1828) (red grouper) and E. striatus (Bloch, 1792) (Nassau grouper) and certain members of the genus Mycteroperca such as M. tigris (Valenciennes, 1833) (tiger grouper) and 
M. venenosa (Linnaeus, 1758) (yellowfin grouper). In fact, most of the grouper remains identified at the Minnis-Ward and North Storr's Lake sites appear to be those of E. morio based upon morphology (Florida Museum of Natural History disarticulated comparative specimen). The serranid atlas width was taken as a lateral measurement at the greatest medio-lateral breadth on the anterior portion of the vertebral centrum (Morales \& Rosenlund, 1979; Reitz, 1994; see also Reitz \& Wing, 1999:176, Fig. 7.3 for an illustration of where the atlas width is taken). The serranid atlas height was taken as the greatest dorsoventral height of the vertebral centrum (Morales \& Rosenlund, 1979; see also Blick, 2006, 2007).

Based upon the serranid atlas width measurement described above, an allometric formula (Reitz \& Wing, 1999; Wing, 2001; Wing \& Wing, 2001) was used to calculate serranid body weight from the atlas width. An allometric formula is an "equation [that] describes the line that statistically best fits the data and is calculated by the method of least squares" (Reitz \& Wing, 1999:70). Using the atlas widths of a particular fish, one can correlate "dimensions of fish skeletal elements and total weight or length" (Reitz \& Wing, 1999:70) of that particular class or family of fish (there are separate formulae for different categories of fishes, so one must chose the formula one uses with care). In this case, for the serranid atlases analyzed for the present chapter, the formula utilized was one derived from a sample of teleost fish atlas widths utilized in other similar studies by Wing (2001) and Wing \& Wing (2001:3, Table 2):

$$
\log \mathrm{Y}=\log \mathrm{a}+\mathrm{b}(\log \mathrm{X})
$$

where:

$\mathrm{X}=$ the measurement of the skeletal element (atlas width, $\mathrm{mm}$ )

$\mathrm{Y}=$ the estimated body weight $(\mathrm{g})$

$\log \mathrm{a}=$ the $\mathrm{Y}$-intercept $(.872)$

$\mathrm{b}=$ the slope of the line (2.53)

Since sample size is largest at the Minnis-Ward site, the total number of identified vertebrate taxa (a measure of "richness") was calculated for each archaeological level in the 5x5 m excavation unit. This simply amounted to a presence/absence analysis of whether a vertebrate taxon was present or not in a particular archaeological level and does not take into account "abundance" (how many individuals or specimens are present within a particular taxon). For each archaeological level, from earliest (deepest) to most recent, the number of taxa present were summed to yield the total number of identified taxa per archaeological level to assess whether or not there was a generally observable decline in taxa richness as one might expect as resources are continuously exploited over time (Newsom \& Wing, 2004; Pauly et al., 1998; Reitz \& Wing, 1999; Wing, 2001; Wing \& Wing, 2001). Prehistoric vertebrate fauna identified in the Minnis-Ward materials include a number of predominantly tropical reef taxa and other fishes, and generally identified Cheloniidae. Intrusive vertebrate fauna include the post-Columbian European introductions of Rattus sp. (Linnaeus, 1758) (rat) and Caprinae (possible Barbadan sheep; Reitz, personal communication, July 2004) which have an associated AMS radiocarbon date of A.D. 16901900 (UGAMS-17156, calibrated, 2-sigma). The post-Columbian introductions were excluded from the analysis of prehistoric change in the total number of identified taxa. The complete list of identified vertebrate taxa at Minnis-Ward is presented in Table 1. 


\begin{tabular}{|c|c|c|c|c|c|c|c|c|}
\hline Family or Taxon & Genus (\& species if possible) & Trophic Level & Level 3 & Level 2 & Level 1 & L3TL & L2TL & L1TL \\
\hline Belonidae & Tylosurus (?) & 4.46 & & & & & & \\
\hline \multirow[t]{3}{*}{ Serranidae } & & & 1 & 1 & 1 & & & \\
\hline & Epinephelus cf. morio & 3.60 & 1 & 1 & 1 & 3.60 & 3.60 & 3.60 \\
\hline & Epinephelus sp. & 3.60 & 1 & 1 & 1 & 3.60 & 3.60 & 3.60 \\
\hline \multirow[t]{2}{*}{ Carangidae } & Caranx cf. latus & 4.36 & 1 & & & 4.36 & & \\
\hline & Caranx sp. & 4.36 & 1 & & & 4.36 & & \\
\hline Lutjanidae & & & & 1 & & & & \\
\hline Haemulidae & Haemulon (?) & 3.27 & & & & & & \\
\hline Sparidae & Calamus cf. bajonado & 3.17 & 1 & 1 & 1 & 3.17 & 3.17 & 3.17 \\
\hline \multirow[t]{3}{*}{ Labridae } & & & 1 & 1 & 1 & & & \\
\hline & Halichoeres cf. radiatus & 3.26 & 1 & 1 & 1 & 3.26 & 3.26 & 3.26 \\
\hline & Halichoeres sp. & 3.26 & 1 & & 1 & 3.26 & & 3.26 \\
\hline \multirow[t]{5}{*}{ Scaridae } & Scarus cf. coelestinus & 2.02 & 1 & 1 & 1 & 2.02 & 2.02 & 2.02 \\
\hline & Scarus cf. vetula & 2.03 & 1 & 1 & 1 & 2.03 & 2.03 & 2.03 \\
\hline & Scarus sp. & 2.02 & 1 & 1 & 1 & 2.02 & 2.02 & 2.02 \\
\hline & Sparisoma cf. rubripinne & 2.00 & 1 & & & 2.00 & & \\
\hline & Sparisoma viride & 2.00 & 1 & 1 & 1 & 2.00 & 2.00 & 2.00 \\
\hline \multirow[t]{2}{*}{ Acanthuridae } & Acanthurus coeruleus & 2.01 & 1 & & & 2.01 & & \\
\hline & Acanthurus sp. & 2.01 & 1 & & & 2.01 & & \\
\hline Scombridae & & & 1 & & & & & \\
\hline Balistidae & Balistes cf. vetula & 3.40 & 1 & 1 & 1 & 3.40 & 3.40 & 3.40 \\
\hline Diodontidae & Diodon & 3.37 & & 1 & & & 3.37 & \\
\hline UID Fish & & & 1 & 1 & 1 & & & \\
\hline Cheloniidae & (Chelonia mydas? - herbivore) & 2.00 & 1 & 1 & 1 & 2.00 & 2.00 & 2.00 \\
\hline UID Bird (Aves) & & & 1 & & & & & \\
\hline Mammal & Rattus (UID Mammal?)* & & & 1 & & & & \\
\hline \multirow[t]{4}{*}{ Mammal } & Caprinae (Barbadan sheep?) ${ }^{* *}$ & & & & 1 & & & \\
\hline & TOTAL & & 21 & 16 & 15 & 2.82 & 2.77 & 2.76 \\
\hline & *possible intrusive/post 1492 & from & & & & & & \\
\hline & ${ }^{* * *}$ possible historic/post 1780 & fishbase.org & & & & & & \\
\hline
\end{tabular}

Table 1. Complete list of identified vertebrate taxa at Minnis-Ward. Trophic levels for each taxon are provided as is taxon presence/absence information for each of the archaeological Levels 3-1. Total numbers of identified taxa are provided in the Total row, as are the average trophic level figures for each archaeological level. Taxa not positively identified, indicated by (?), and historic/intrusive taxa, have been left out of the pre-Columbian trophic level calculations. Trophic levels are based on Froese \& Pauly (2005). Note: L3TL = Level 3 trophic level, etc.

Each of the vertebrate taxa identified at Minnis-Ward was assigned a trophic level which is basically an animal's place in the food chain. These trophic levels are based on Pauly et al. (1998) and Froese \& Pauly (2005) who rank primary producers as 1 and apex predators near 5. Trophic level values (and their explanations) for each of the identified taxa are available on the Internet at www.fishbase.org (Froese \& Pauly, 2005). The trophic level analysis of Wing (2001; Wing \& Wing, 2001) was inspirational and subsequently modified for specific application to the available archaeological dataset from the Minnis-Ward site for the purposes of this chapter. Utilizing the presence/absence analysis of the number of identified taxa (described above), each taxon was assigned a 1 or a 0 if it was present or absent, respectively, in a particular archaeological level. The trophic levels for each individual taxon were then multiplied by a 1 if the taxon was present or a 0 if the taxon was absent, summed 
within each archaeological level, and an average or mean trophic level was then calculated for each of the archaeological strata or excavated levels (Table 1). This allowed for a general, yet revealing, analysis of prehistoric change in trophic level across time as represented by each of the archaeological strata from earliest (deepest) to most recent.

\section{Results}

Beginning with our invertebrate fauna, there were significant declines over time in the weight of Gecarcinidae (land crab) remains at both the Minnis-Ward site (SS-3) and North Storr's Lake (SS-4). In the three archaeological levels at Minnis-Ward on the northwestern corner of San Salvador, weight of land crab remains declines linearly from $56.1 \mathrm{~g}$ in Level 3 to $19.1 \mathrm{~g}$ in Level 1 (Figure 3). The approximate time frame of this decline is ca. A.D. 8801490 (calibrated, 2 sigma) based on previously reported radiocarbon dates for the MinnisWard site (Blick, Creighton, \& Murphy, 2006, Appendix 1; Blick \& Dvoracek, 2011; Winter, 1981, 1997). The significance of this decline was measured using a likelihood ratio test (Myers et al., 1995) with Poisson distribution yielding $\mathrm{p}=0.00001$. The likelihood ratio test was utilized rather than linear correlation due to the sample size of archaeological levels involved $(n=3)$, although it should be noted that there are hundreds of crab fragments per archaeological level that contributed to the total weight for each level (total of 687 land crab fragments in all three levels combined). This likelihood ratio test assumes that the average weight per fragment per level is equal, an assumption validated through the construction of confidence intervals for the counts and weights of Gecarcinidae fragments for each archaeological level (Jason Stover, personal communication, April 2005). At the North Storr's Lake site on the northeastern side of San Salvador, weight of Gecarcinidae remains declines in near-linear fashion from $50.0 \mathrm{~g}$ in Level 5 to $15.1 \mathrm{~g}$ in Level 1 (Figure 3). The approximate time frame of this decline is ca. A.D. 1300-1520 (calibrated, 2-sigma) based on recent AMS radiocarbon dates from North Storr's Lake (Blick \& Dvoracek, 2011; Blick, Creighton, \& Murphy, 2006, Appendix 1). The significance of this decline was measured using a likelihood ratio test with Poisson distribution yielding $\mathrm{p}<0.001$. The likelihood ratio test was utilized rather than linear correlation due to the sample size of archaeological levels involved $(n=5)$, although it should be noted that there are hundreds of crab fragments per archaeological level that contributed to the total weight for each level (total of 1320 land crab fragments in all five levels combined).

Weight of the mollusk C. pica remains declines significantly at the Minnis-Ward site from $402.4 \mathrm{~g}$ in Level 3 to $97.5 \mathrm{~g}$ in Level 1 (Figure 4). The approximate time frame of this decline is ca. A.D. 880-1490 (calibrated, 2-sigma) based on previously reported radiocarbon dates for the Minnis-Ward site (Blick, Creighton, \& Murphy, 2006, Appendix 1; Blick \& Dvoracek, 2011; Winter, 1981, 1997). The significance of this decline was measured using a likelihood ratio test with Poisson distribution yielding $\mathrm{p}=0.012$. The likelihood ratio test was utilized rather than linear correlation due to the sample size of archaeological levels involved $(n=3)$ although it should be noted that there are tens to hundreds of $C$. pica fragments per archaeological level that contributed to the total weight for each level (total of 277 C. pica fragments in all three levels combined). Another mollusk, S. gigas, also exhibits a dramatic decline in raw count at the Minnis-Ward site (Blick, 2004:16, Tables 3 and 4), indicative of general decline in mollusks over time. 
Similarly, weight of chiton (C. tuberculatus/A. granulata) remains declines significantly at the Minnis-Ward site from $131.9 \mathrm{~g}$ in Level 3 to $64.3 \mathrm{~g}$ in Level 1 (Figure 5). The approximate time frame of this decline is ca. A.D. 880-1490 (calibrated, 2-sigma) based on previously reported radiocarbon dates for the Minnis-Ward site (Blick, Creighton, \& Murphy, 2006, Appendix 1; Blick \& Dvoracek, 2011; Winter, 1981, 1997). The significance of this decline was measured using a likelihood ratio test with Poisson distribution yielding $p=0.0211$. The likelihood ratio test was utilized rather than linear correlation due to the sample size of archaeological levels involved $(n=3)$ although it should be noted that there are dozens of chiton fragments per archaeological level that contributed to the total weight for each level (total of 143 chiton fragments in all three levels combined).

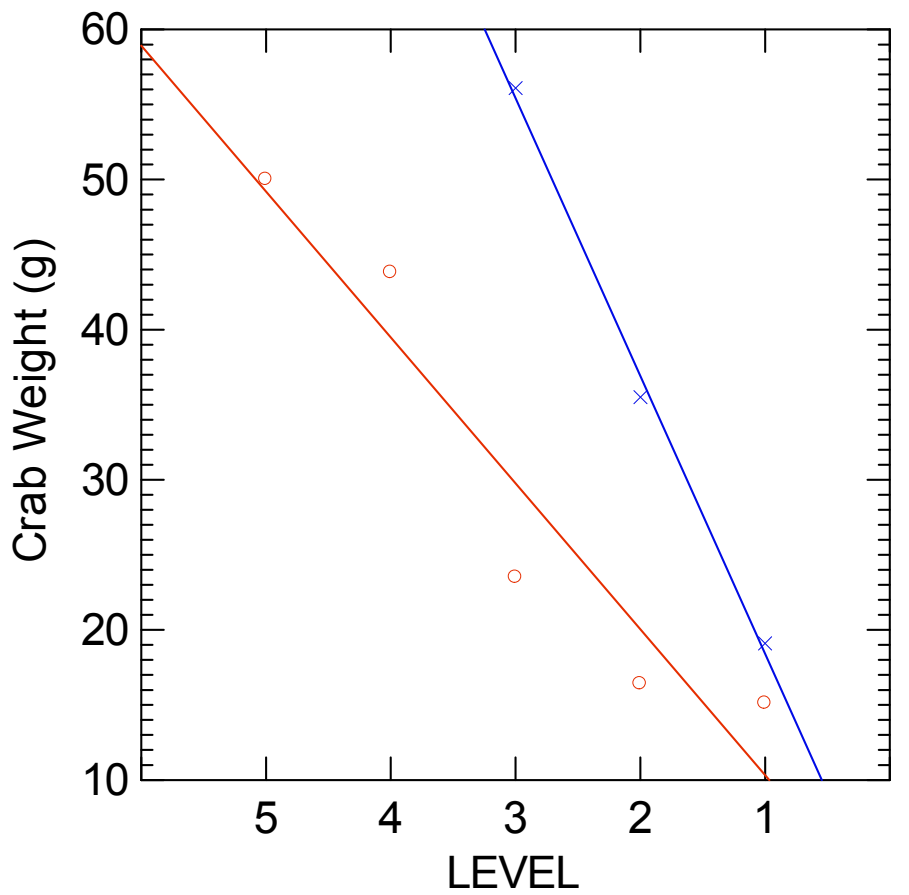

Fig. 3. Decline in weight of Gecarcinidae (land crab) remains at the Minnis-Ward site ( $x$, blue) from Level 3 to Level 1, ca. A.D. 880-1490 (likelihood ratio test with Poisson distribution, $\mathrm{n}=687, \mathrm{p}=0.00001$, least squares line: $\mathrm{y}=-18.5 \mathrm{x}+0.60)$ and decline in weight of land crab remains at the North Storr's Lake site (o, red) from Level 5 to Level 1, ca. A.D. 1300-1520 (likelihood ratio test with Poisson distribution, $\mathrm{n}=1320, \mathrm{p}<0.001$, least squares line: $y=-8.725 x+6.375)$. Open circles represent total weights of crab remains per stratigraphic level.

Moving from the invertebrate to the vertebrate fauna, analysis of the width of the LPGM of the parrotfish $S$. viride reveals a statistically significant decline in size over time from an average of $13.102 \mathrm{~mm}$ in Level 3 to $12.106 \mathrm{~mm}$ in Level 1 (Figure 6). Once again, the approximate time frame of this decline is ca. A.D. 880-1490 (calibrated, 2-sigma) based on previously reported radiocarbon dates for the Minnis-Ward site (Blick, Creighton, \& 
Murphy, 2006, Appendix 1; Blick \& Dvoracek 2011; Winter, 1981, 1997). The significance of this decline was measured using analysis of variance by examining the average width of LPGMs per archaeological level $(n=249$, F-ratio $=3.747, p=0.025)$. Likewise, analysis of the length of the LPGMs of $S$. viride reveals a moderately significant decline in size over time from an average of $11.210 \mathrm{~mm}$ in Level 3 to $10.313 \mathrm{~mm}$ in Level 1 over the same time frame mentioned above. The significance of this decline was measured using analysis of variance by examining the average length of LPGMs per archaeological level $(n=192$, F-ratio $=2.361$, $\mathrm{p}=0.097$, i.e., there is $<10$ percent probability that the observed difference is due to random chance). Therefore, both the width and the length of the $S$. viride LPGM exhibit statistically significant declines in average size over time, reflecting decline in the average size of the entire organism. "Animals under intense predation show a decline in size as a result of overexploitation" (Southerland, 1990 in Reitz \& Wing, 1999:67; see also Coleman et al., 2004; Conover \& Munch, 2002; Pauly et al., 1998). Similar declines in the width and length of $S$. viride LPGMs have also been observed at the North Storr's Lake site (SS-4) during the period ca. A.D. 1300-1520 (calibrated, 2-sigma), although current sample sizes are not statistically adequate to verify this trend (Blick, 2007).

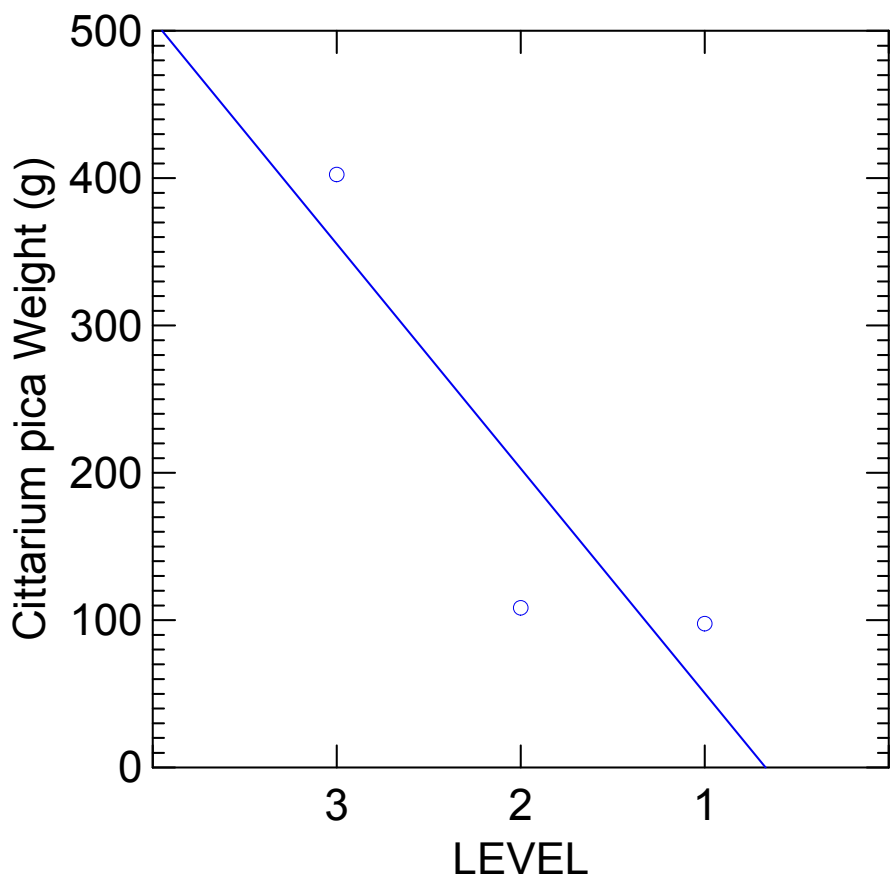

Fig. 4. Decline in weight of Cittarium pica (West Indian top shell) remains at the MinnisWard site from Level 3 to Level 1, ca. A.D. 880-1490 (likelihood ratio test with Poisson distribution, $\mathrm{n}=277, \mathrm{p}=0.012$, least squares line: $\mathrm{y}=-152 \mathrm{x}+-104)$. Open circles represent total weights of $C$. pica remains per stratigraphic level.

Measurements of the widths of Serranidae atlases from the Minnis-Ward site reveal a bimodal distribution likely indicative of the exploitation of different sized serranids and/or 
the use of different fishing techniques (Figure 7), a finding similar to that of Reitz (1994) for grouper on Montserrat. For example, it is generally the case that nets or traps are used to catch smaller fish and that hook and line are more effective in catching larger fish (Froese \& Pauly, 2005; Keegan, 1986; Wing \& Reitz, 1982), especially predatorial serranids like E. morio and E. striatus that are more likely to take bait from a hook (Froese \& Pauly, 2005; Ostrander \& Brocksmith, 1997). The bimodal distribution of Serranidae atlases in Figure 7 was shown to be statistically significant through the use of a Kolmogorov-Smirnov (K-S) test for normality to determine if two different populations are represented in the sample. The results of the K-S test were based on a sample size of $\mathrm{n}=30(\mathrm{D}=1.000, \mathrm{p}<0.0001)$; a t-test also indicated a significant difference between the two serranid populations $(\mathrm{n}=30, \mathrm{t}=$ $11.294, \mathrm{p}<0.0001)$. These results were also confirmed with hierarchical cluster analysis and K-means cluster analysis (Figure 8) $($ F-ratio $=122.248, \mathrm{p}<0.0001$ ) that divided the serranids into two natural clusters with a clear divide in atlas widths at ca. $15 \mathrm{~mm}$.

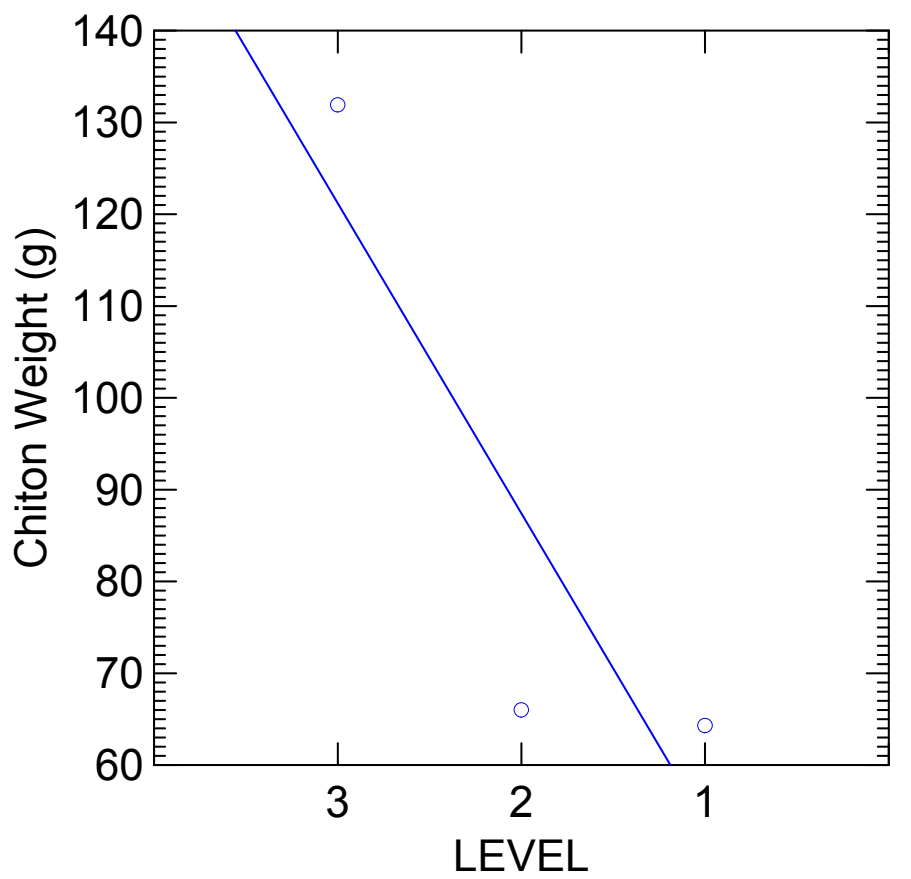

Fig. 5. Decline in weight of chiton remains at the Minnis-Ward site from Level 3 to Level 1, ca. A.D. 880-1490 (likelihood ratio test with Poisson distribution, $n=143, p=0.0211$, least squares line: $y=-34.2 x+18.6)$. Open circles represent total weights of chiton remains per stratigraphic level.

Using the allometric formula to calculate fish weight from the atlas width (Wing, 2001; Wing \& Wing, 2001), two groups of serranids result: Size Group 1 or the smaller serranids with an average atlas width of $11.219 \mathrm{~mm}$ (range 9.20-13.20 mm) estimated to weigh an average of $3470.13 \mathrm{~g}(7.65 \mathrm{lb})$ (range 2043.54-5093.92 g), and Size Group 2 or the larger serranids with an average atlas width of $18.047 \mathrm{~mm}$ (range 15.75-21.60 mm) with an estimated body weight 
averaging 11,456.66 $\mathrm{g}(25.26 \mathrm{lb}$ ) (range 7963.79-17,707.94 g) (Figure 9). It is therefore hypothesized that the smaller serranids were likely caught in traps while the larger serranids were more likely taken with hook and line. Additional analyses of the widths and heights of Serranidae atlases at Minnis-Ward reveal a general decline in size over time during the period ca. A.D. 880-1490, although these declines are not statistically significant at the 0.05 level due to small sample size (especially per-level sample size) (Figure 10).

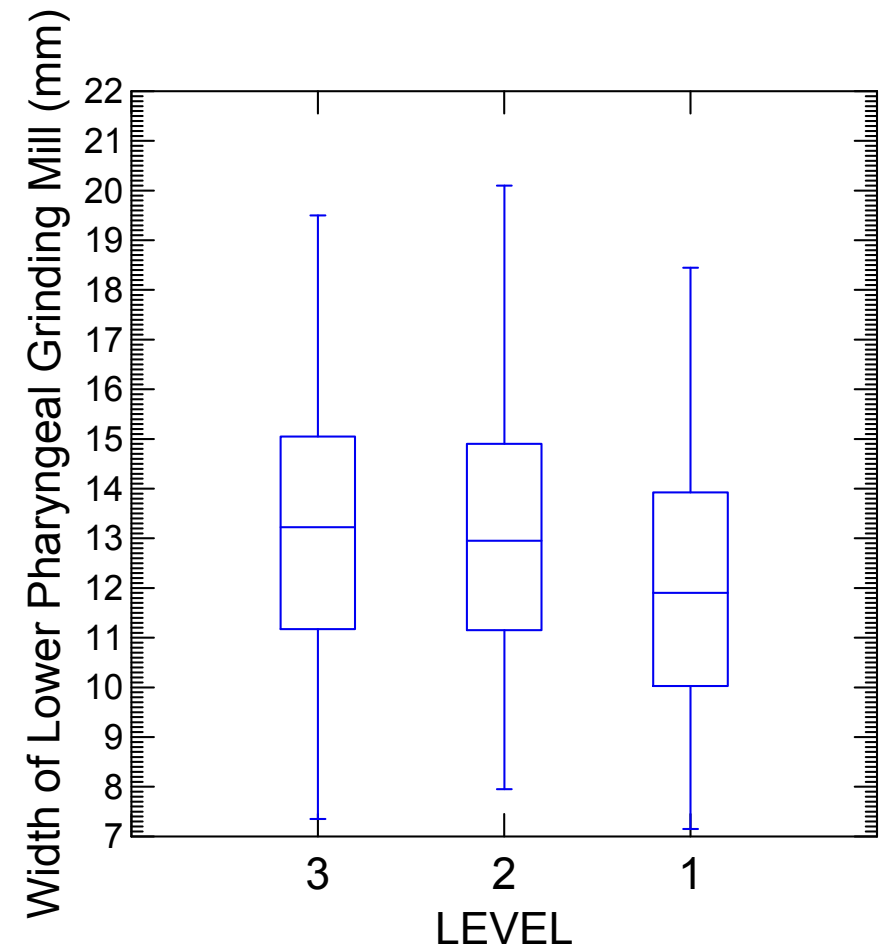

Fig. 6. Decline in the width of the lower pharyngeal grinding mill of Sparisoma viride (stoplight parrotfish) at the Minnis-Ward site from Level 3 to Level 1, ca. A.D. 880-1490 (ANOVA, $\mathrm{n}=$ 249 , F-ratio $=3.747, p=0.025$ ). Each of the box plots shows median LPGM width (horizontal line within box), interquartile range (box), and range (whiskers) for each stratigraphic level.

The total number of identified taxa shows a notable decline over time from 21 total taxa in Level 3 to 14 taxa in Level 1 (Figure 11). The approximate time frame of this decline is ca. A.D. 880-1490 (calibrated, 2-sigma) based on previously reported radiocarbon dates for the Minnis-Ward site (Blick, Creighton, \& Murphy, 2006, Appendix 1; Blick \& Dvoracek, 2011; Winter, 1981,1987). This decline is not amenable to statistical analyses of the sort presented previously in this chapter due to the way the data were lumped into three archaeological levels yielding a sample size of $n=3$. If one were to attempt linear correlation analysis to describe the strength of the decline in the total number of identified taxa in Level 3 to Level 1 , one would find $r=0.952$ and $r^{2}=0.855$, but linear correlation is not amenable to a sample size of three levels. It is clear from the slope of the line in Figure 11 that the decline in 
identified taxa is dramatic, especially between Levels 3 and 2. Based on an AMS radiocarbon date of A.D. 1000 \pm 40 (UGAMS-17157, calibrated, 2-sigma) for Level 3 (Blick \& Dvoracek, 2011; Blick, Creighton, \& Murphy, 2006, Appendix I), it is clear that total number of identified taxa (taken as a proxy for taxa richness) is higher during the earlier preColumbian period (ca. A.D. 900-1150) than in later pre-Columbian times (ca. A.D. 1300-1490) at Minnis-Ward. Decline in ecosystem richness is generally interpreted as resulting from human overexploitation, in this case fishing pressure, although other ecological factors may also be responsible (e.g., climate change, see Discussion, below).

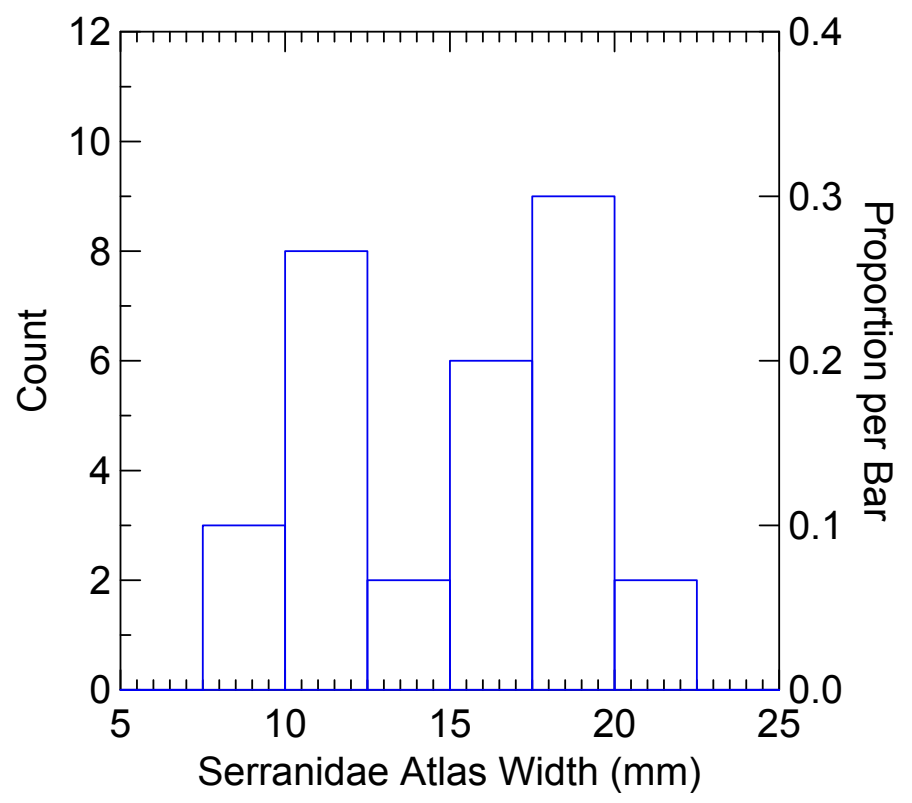

Fig. 7. The bimodal distribution of Serranidae (sea bass/grouper) atlases at the Minnis-Ward site is statistically significant based on the results of a Kolmogorov-Smirnov test $(\mathrm{n}=30, \mathrm{D}=$ $1.000, \mathrm{p}<0.0001)$ and a t-test $(\mathrm{n}=30, \mathrm{t}=-11.294, \mathrm{p}<0.0001)$. This morphological dichotomy suggests different sized serranids were caught using different fishing techniques.

Likewise, the average trophic levels for archaeological Levels 3 through 1 at Minnis-Ward decline over time from a mean of 2.819 to 2.760 (on a scale of 1 to 5) (Figure 12). This decline in trophic level is similar in scale to that reported by Wing \& Wing (2001, Fig. 6) for Nevis, Puerto Rico, Saba, St. Martin, and St. Thomas during the period ca. A.D. 100-1390. The approximate time frame of this decline at Minnis-Ward is ca. A.D. 880-1490 (calibrated, 2sigma). The decline in trophic levels is not amenable to statistical analyses of the sort presented previously in this report due to the way the data were lumped into three archaeological levels yielding a sample size of $n=3$. If one were to attempt linear correlation analysis to describe the strength of the decline in the average trophic levels from Levels 3 through Level 1, one would find $r=0.933$ and $r^{2}=0.871$, but linear correlation is not amenable to a sample size of three. Based upon the same taxa dataset, yet calculated in a different manner (Table 1), the decline in average trophic level is notable, especially between 
Levels 3 and 2. It is clear, therefore, that the average trophic level is higher in earlier preColumbian times (ca. A.D. 900-1150) and had declined substantially by late prehistoric times (ca. A.D. 1300-1490). Such a decline in trophic level is generally interpreted as a result of overfishing (Pauly et al., 1998; Wing \& Wing, 2001) and is symptomatic of the phenomenon known as "fishing down the marine food web" (Pauly et al., 1998). Not only does the average trophic level decline over time from Level 3 to Level 1 at the Minnis-Ward site, but a change in community composition was observed over time. For example, in Level 3 dated to A.D. $1000 \pm 40$ (calibrated, 2-sigma), the average trophic level is 2.819 and there are both more carnivores and more herbivores among the identified taxa (Figure 13). The higher level carnivores consist of positively identified Caranx latus (Agassiz in Spix \& Agassiz, 1831) (horse-eye jack) and a more generally identified member of the genus Caranx sp. (jack). Other fishes in the middle of the trophic scale in archaeological Level 3 include E. morio and a more generally identified member of the genus Epinephelus, Balistes vetula (Linnaeus, 1758) (queen triggerfish), Halichoeres radiatus (Linnaeus, 1758) (puddingwife) and Halichoeres sp., and positively identified Calamus bajonado (Bloch \& Schneider, 1801) (jolthead porgy).

\section{Cluster Tree}

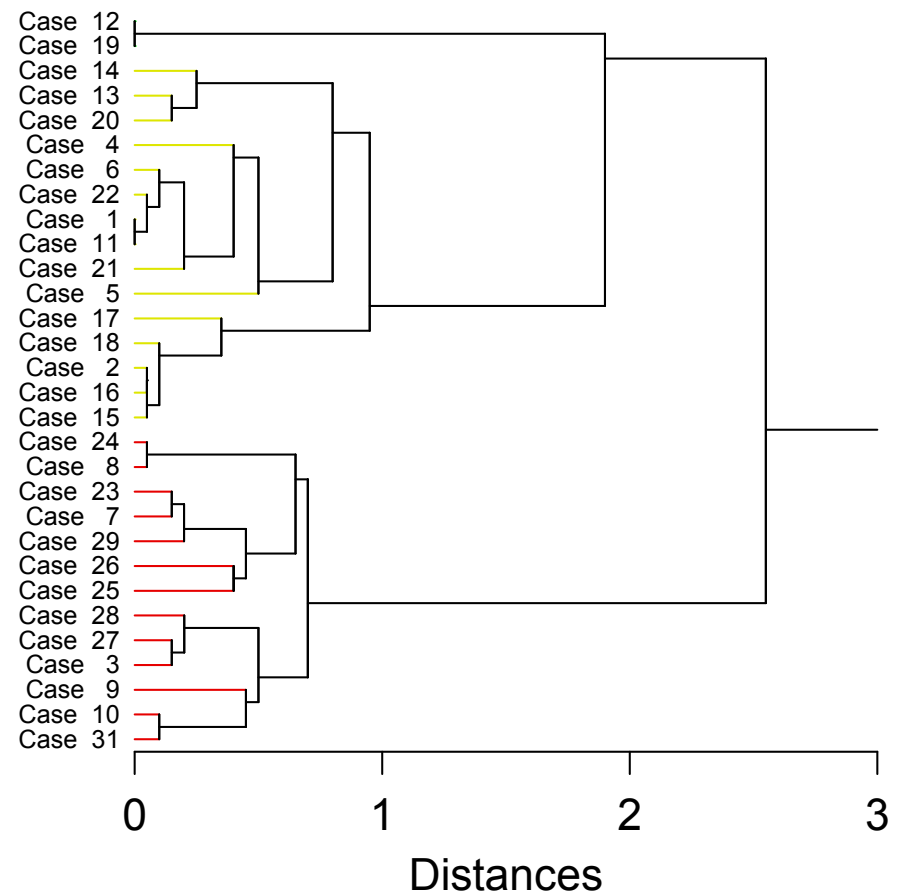

Fig. 8. K-means cluster analysis $(n=30$, F-ratio $=122.248, \mathrm{p}<0.0001)$ divides the Serranidae at the Minnis-Ward site into two natural clusters with a clear divide in atlas widths at ca. 15 $\mathrm{mm}$ (compare to Figures 7 and 9). 
Fishes and other organisms ranked as herbivores in Level 3 include a variety of Scaridae, Acanthuridae, and even Cheloniidae, probably Caretta caretta (Linnaeus, 1758) (loggerhead turtle) (Table 1). In Level 2, the carnivorous Caranx spp. are no longer present, the mid-level Halichoeres sp. disappears, and the herbivorous Sparisoma rubripinne (Valenciennes, 1840) (yellowtail parrotfish) and Acanthurus spp. (tangs) are missing. Level 2 gains a mid-level feeder with the presence of Diodon, probably D. hystrix (Linnaeus, 1758) (porcupinefish), while Level 1 has the same taxa as Level 2 with the exception of Diodon and the reappearance of Halichoeres sp. Clearly, the decline in average trophic level and the change in community composition are more pronounced from Level 3 to Level 2 and continue to a lesser degree in Level 1 . The significance of this alteration in community composition as a response to human exploitation will be addressed in more detail below.

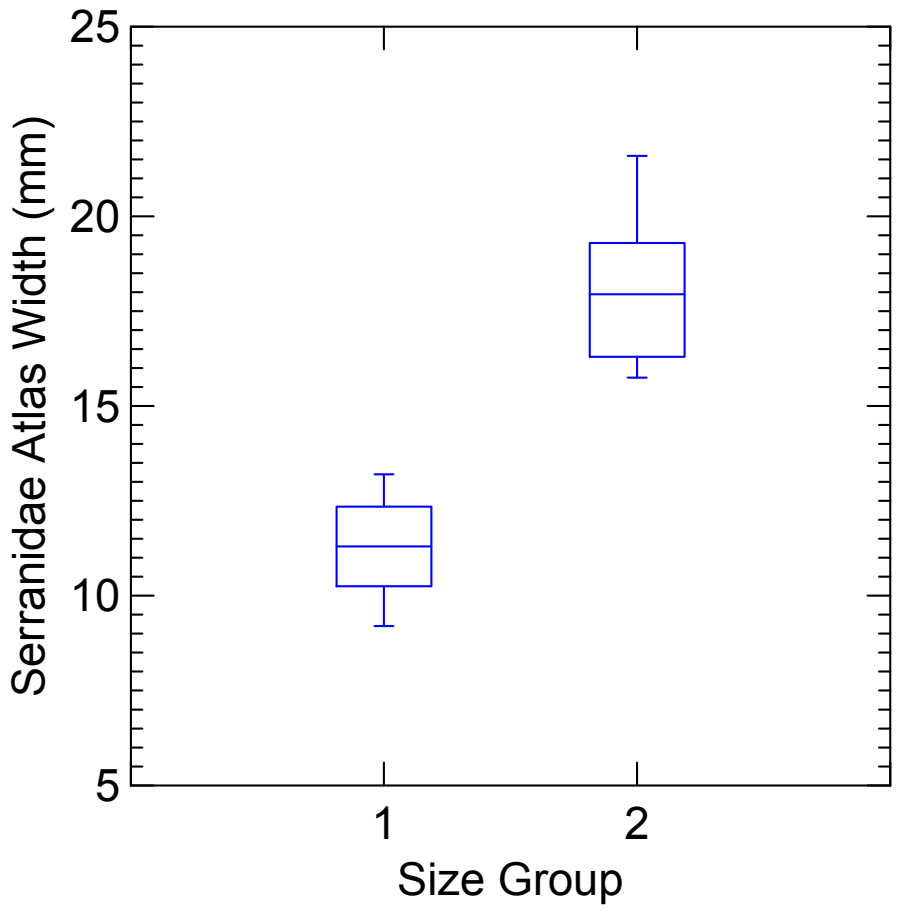

Fig. 9. Two size groups of Serranidae at the Minnis-Ward site $(n=30, t=-11.294, p<$ 0.000001). An allometric formula to calculate fish body weight from atlas width (see text) indicates that the smaller serranids, with an average atlas width of $11.387 \mathrm{~mm}$, have an estimated mean body weight of $3470.13 \mathrm{~g}(7.65 \mathrm{lb})$; the larger serranids, with an average atlas width of $18.047 \mathrm{~mm}$, have an estimated mean body weight of 11,456.66 $\mathrm{g}(25.26 \mathrm{lb})$. Each of the box plots show median atlas width (horizontal line within box), interquartile range (box), and range (whiskers) for each stratigraphic level.

\section{Discussion}

The time period of the declines of the weights and sizes of the various organisms discussed in this chapter basically covers the majority of the pre-Columbian occupation on the island 
of San Salvador. Prehistoric deposits at the Minnis-Ward site (SS-3) date to ca. A.D. 880-1490 (calibrated, 2-sigma) with Level 3 dating to ca. A.D. 900-1150, Level 2 corresponding to ca. A.D. 1150-1300, and Level 1 representing the latest pre-Columbian period, ca. A.D. 13001490. Historic era radiocarbon dates from Minnis-Ward dating to the English colonization and Loyalist periods, ca. A.D. 1670-1900 and later, are associated with historically introduced material culture remains not considered in this chapter. Thus, the changes observed in the invertebrate and vertebrate fauna at Minnis-Ward described above occurred during the ca. 600-year period between ca. A.D. 880 to just prior to the arrival of Columbus in the Bahamas. Deposits from Blick's 2005 excavation at North Storr's Lake (SS-4) appear to date fairly late in the prehistoric sequence and cover a range from ca. A.D. 1300-1520 (Blick \& Dvoracek 2011; Blick \& Murphy, 2005; Blick, Creighton, \& Murphy, 2006, Appendix I). Level 3 in the middle of the stratigraphic column at North Storr's Lake dates clearly to A.D. 1300-1370 (UGAMS-17152, calibrated, 2-sigma) while the more superficial Level 2 dates to A.D. 1390-1490 (UGAMS-17151, calibrated, 2-sigma). Therefore it is apparent that the deposit excavated by Blick at North Storr's Lake represents the last ca. 200 years before the arrival of Columbus. Yet at both Minnis-Ward and North Storr's Lake, despite their varying durations of occupation, it is possible to detect prehistoric human impact on the ancient environment through the analysis of changing weights, quantities, and sizes of biological organisms utilized by the Lucayans as food resources.

The statistically significant diminution in the abundance of Gecarcinidae at both MinnisWard (SS-3) and North Storr's Lake (SS-4) is reminiscent of the decline in land crab abundance first noted by Rainey (1940) on pre-Columbian sites in Puerto Rico. Likewise, this decline in land crab remains has been noted on many Caribbean islands such as Antigua (Jones, 1985), Nevis, Puerto Rico, Saba, St. Martin, St. Thomas (Wing, 2001; Wing, deFrance, \& Kozuch, 2002), St. John's (Quitmyer, 2003), St. Kitts (Goodwin, 1980), and several islands of the French Lesser Antilles (Serrand, 2002). Today, this trend is recognized as a widespread phenomenon in the archaeological record of the Greater Caribbean (Serrand, 2002). Factors such as climate change, habitat destruction, and human overexploitation have all been proposed as mechanisms for this pan-Caribbean decline in Gecarcinidae remains. Carlson \& Keegan (2004:88), for example, have suggested that the decline in land crab remains (and subsequent replacement by mollusks in the diet) might have been due to "increased aridity at the end of the Saladoid period" (ca. A.D. 500). The climate change explanation for the decline in land crab abundance fails simply due to the fact that the decline in crab is observed at different time periods from relatively early in the Saladoid sequence (ca. A.D. 100-400) into later prehistory (ca. A.D. 1000-1500) (e.g., Newsom \& Wing, 2004). It is possible that habitat destruction due to agricultural practices (Jones, 1985) may have played a role in the decline of Gecarcinidae, but the most widely accepted explanation for this decline now appears to be human overexploitation of land crabs (Blick, 2006, 2007; Newsom \& Wing, 2004; Serrand, 2002; Wing, 2001; Wing, DeFrance, and Kozuch, 2002). Hill (2001:6) gives us an idea of the intensity of this crab exploitation (in modern times): "Throughout the Bahamas and Caribbean, Cardisoma guanhumi is intensively exploited as a food resource. Harvesters of wild populations ... have reported that as many as 400 crabs per harvester per night can be collected even during the months of lowest catch" (see also LaPilusa \& Heilveil, 2011 for modern festival-related crab harvesting on Andros Island).

The statistically significant decline of $C$. pica at the Minnis-Ward site resembles declines in abundance reported for other islands in the Caribbean such as Jamaica (Keegan, Portell, \& 
Slapcinsky, 2003), Saba, St. John, St. Martin, St. Thomas, and Nevis (Quitmyer, 2003; Wing, 2001; Wing, deFrance, \& Kozuch, 2002). At rare sites, there has been confusion regarding natural vs. human deposits of C. pica (Scudder \& Quitmyer, 1998), but the majority of archaeological sites seems to provide evidence of $C$. pica as a substantial contributor to the pre-Columbian Caribbean diet (Jones, 1985; Keegan, 1992; Keegan, Portell, \& Slapcinsky, 2003; Newsom \& Wing, 2004; Wing, 2001; Wing, deFrance, \& Kozuch, 2002). Rainey (1940) indicated that with the decline of the Gecarcinidae there was a concomitant rise in the abundance of mollusks, especially C. pica. If measured by weight, however, there appears to be a synchronous decline in land crab as well as C. pica (see for example Wing, 2001:115, Table 2). C. pica is also recorded to decline in size at many Caribbean sites where aperture measurements have been taken (Quitmyer, 2003; Wing, deFrance, \& Kozuch, 2002). Therefore, C. pica, throughout the Greater Caribbean, appears to have been subject to the same intensive harvesting pressures as the terrestrial Gecarcinidae, despite C. pica's rocky intertidal habitat, to the point of local extirpation in some cases (Keegan, Portell, \& Slapcinsky, 2003). Decline in the quantity of $S$. gigas at Minnis-Ward mirrors the decline in C. pica due to high levels of exploitation throughout the Greater Caribbean (Keegan, 1992; Keegan, Portell, \& Slapcinsky, 2003; Robertson, 2003). Patterns of decline in abundance in both of these organisms (C. pica and S. gigas) reflect a major reliance upon mollusks as preferred high-ranking protein sources (Keegan, 1992:132, Table 6.1).

The statistically significant decline of Chiton tuberculatus/Acanthopleura granulata at MinnisWard echoes the trends of decline in abundance of Gecarcinidae and other edible mollusks (C. pica, S. gigas) previously reported. Although apparently neither well studied nor well reported, the decline in chiton is best explained by human overexploitation. The steady decline of chiton quantity and weight from Level 3 to Level 1 suggests depletion of the resource or its gradual abandonment as a dietary item. Chiton's presence in an archaeological context is definitely a sign of human transport from its rocky intertidal habitat, and these organisms were likely consumed in prehistoric times as they are today by some of the inhabitants of San Salvador (Blick, 2003). Although similar in kilocalories per $\mathrm{kg}$ and grams of protein per $\mathrm{kg}$ to the more preferred S. gigas and C. pica (Keegan, 1992:132, Table 6.1), Keegan (1992:130) considers chiton to be a "low value" food "exploited during periods of food shortage" and "among the last items added to the diet." It is interesting to note that the decline in chiton is synchronous with the declines in abundance and size of many other organisms reported herein. However, rather than a non-preferred starvation food as implied by Keegan, it is likely that chiton was being exploited like any other food resource. The generally low numbers of chiton throughout the deposits at Minnis-Ward (SS3) and North Storr's Lake (SS-4) suggest that chiton occurred as a normal part of the Lucayan diet, although in very small quantities (Blick \& Murphy, 2005).

The statistically significant declines in both the width and length of $S$. viride LPGMs from Level 3-1 at Minnis-Ward provide some of the most striking evidence in this chapter of the effects of pre-Columbian resource overexploitation. Similar declines are also noted at North Storr's Lake, although the sample sizes are too small to yield valid statistics (Blick, 2007). Declining sizes of parrotfishes have been reported for other islands in the Caribbean such as Nevis, Puerto Rico, Saba, St. Martin, and St. Thomas (Newsom \& Wing, 2004; Wing, 2001; Wing, deFrance, \& Kozuch, 2002, Wing \& Wing, 2001). Declining size is one of the chief patterns that indicate that $S$. viride (and other reef fishes) was heavily exploited in 
prehistoric times (Wing \& Wing, 2001). The statistically significant decline in the size of the LPGM is taken as representative of decline in size of the overall organism. In the words of Newsom \& Wing (2004:54), "Overexploitation can manifest itself in many ways and cause population changes. Chief among these in terms of faunal resources is size change. ... Overexploitation by artisanal or subsistence fishermen and gatherers can result in a decline in the body size of territorial organisms," such as coral reef dwelling parrotfishes (Wing \& Wing, 2001). This size (and age structure) reduction is a result of what some scholars have termed growth overfishing - essentially catching fish before they have time to grow to maturity (Newsom \& Wing, 2004; Russ, 1991). More on growth overfishing will be discussed in the next section on Serranidae atlas measurements.

The two clusters of Serranidae atlases demonstrate two significantly different size groups of serranids (sea basses/groupers) at the Minnis-Ward site likely caught using two different capture techniques: nets or traps for the smaller (ca. $3470.13 \mathrm{~g}, 7.65 \mathrm{lb}$ ) serranids, and hook and line for the larger (ca. 11,456.66 g, $25.26 \mathrm{lb}$ ) serranids (Reitz, 1994; Wing 2001). For the purposes of the present discussion concerning overfishing, the most important result is that both serranid atlas width (and height) show declines in size over time from Level 3 to Level 1 at Minnis-Ward (Figure 10), although sample sizes are relatively small $(n=30)$, especially perlevel sample size. These declines in serranid average atlas widths and heights mirror the declines reported for Serranidae on St. Thomas and Nevis (Wing \& Wing, 2001). Serranidae atlases also become less common in the deposits at Minnis-Ward, a trend noted for St. Thomas and Saba (Wing \& Wing, 2001:5): "Serranids that dominated the early samples [periods] were less dominant or absent in the later samples." The trend of declining atlas size for the serranids suggests three possibilities: 1) there was a gradual decline in serranid size over time; 2) serranids targeted in the earlier time period (Level 3) were slightly larger than targeted serranids in the later time periods (Levels 2 and 1); and/or, 3) the different size groups were caught with different harvesting technologies during the different time periods (sample size is currently too small to rigorously test these three hypotheses). Whichever the case, the decline in size of the serranid atlases over time suggests, once again, the phenomenon of growth overfishing (especially notable from Levels 3 to 2), with fishing selection pressure possibly resulting in some somatic size recovery in the latest pre-Columbian period, Level 1 (Conover $\&$ Munch, 2002). The decline in Serranid abundance (as reflected by the number of atlases) in later levels at Minnis-Ward indicates earlier targeting of higher level predatorial feeders and eventual altered composition of the coral reef community due to the removal of higher level predators by selective fishing practices (Wing, 2001; Wing \& Wing, 2001) (more on the alteration of community composition due to overfishing will be discussed below). The decline of the predatorial serranids and the persistence of the herbivorous parrotfishes is likely due to the fact that, "Large predators such as groupers (Serranidae) ... are more vulnerable to overfishing than reef herbivores" (Wing, 2001, citing Russ, 1991).

It should be noted at this point that the evidence from both the S. viride LPGMs and the Serranidae atlases is strongly suggestive of growth overfishing (Russ, 1991; Wing, 2001; Wing, deFrance, \& Kozuch, 2002; Wing \& Wing, 2001). To find similar evidence in two such disparate groups of fishes is certainly striking. While both reef dwelling fishes, clearly the herbivorous $S$. viride and the carnivorous Serranidae both exhibit smaller average body sizes (as indicated by their particular skeletal elements) in the later deposits than in the earlier ones. Even though reef fishes, such as parrotfishes, are usually caught in traps and more aggressive predators are 
typically caught with hook and line (Wing, deFrance, \& Kozuch, 2002), both the S. viride and the Serranidae were being subjected to significant harvesting pressures at the same time. Growth overfishing is typically indicated by decline in body size of the targeted taxon as larger, older fish are removed from the population while smaller, younger fish escape harvest. Eventually, larger older fish become rare, and smaller younger fish become more common, resulting in declining average body size of the targeted taxon over time. While some might choose to debate whether the size changes described above are due to growth overfishing or some other factor, zooarchaeologists point to such changes as clear evidence of stress in the exploited species (Wing, 2001; Wing, deFrance, \& Kozuch, 2002; Wing \& Wing, 2001).

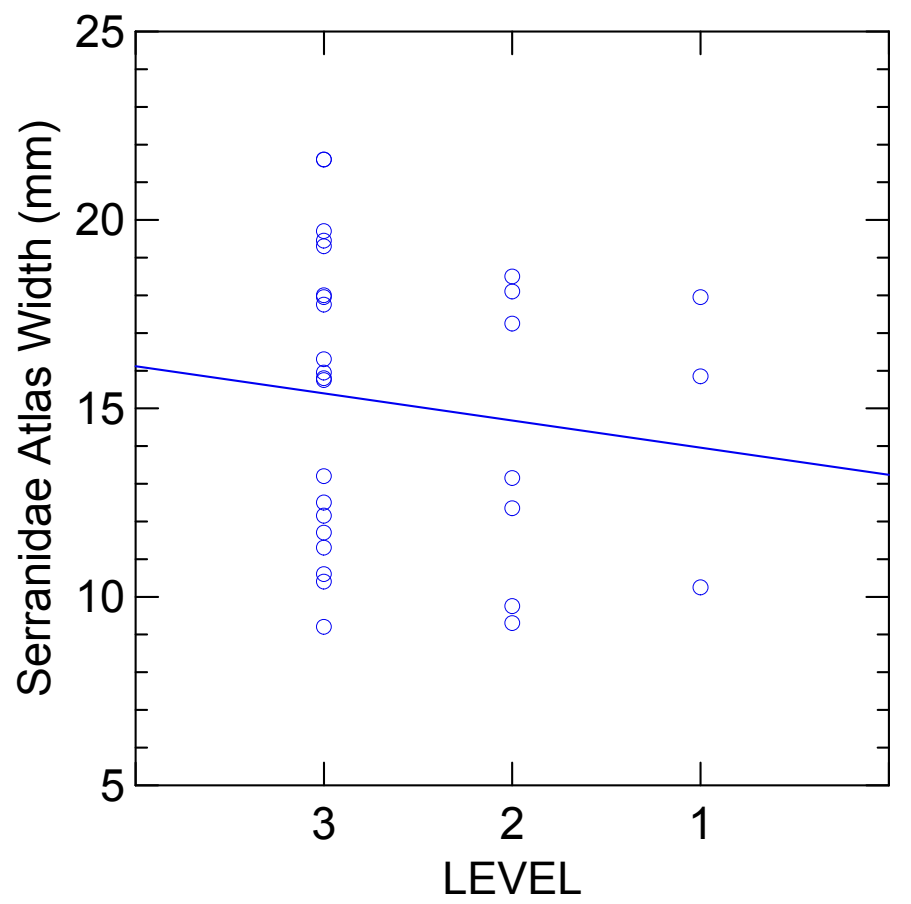

Fig. 10. Decline in Serranidae atlas widths at the Minnis-Ward site from Level 3 to Level 1, ca. A.D. 880-1490, suggestive of reduction in fish size over time $(n=30, p=0.097$, least squares line: $\mathrm{y}=-0.725+16.1)$. Open circles represent individual atlas widths.

The decline in total number of identified taxa at the Minnis-Ward site is a rough measure of decline in taxa richness, or biodiversity. This decline is indeed dramatic and exhibits a drop of 33 percent (from 21 to 14) in identified taxa from the earliest pre-Columbian level to the latest. It is a known fact that island ecosystems are especially vulnerable to human-induced environmental change, including reduction in the number of endemic species (Bahn \& Flenley, 1992; Burney, 1997; Newsom \& Wing, 2004; Steadman, 1995). It is interesting to note that a rare bone of Aves (bird) appears in the vertebrate fauna of the earlier Level 3 but not in later pre-Columbian levels - island birds are known to be highly susceptible to human predation (Steadman, 1995). The pattern observed in the Minnis-Ward marine vertebrate assemblage is not simply due to growth overfishing. This trend represents a transition from 
a fairly abundant pre-Columbian vertebrate fauna (mostly fishes and sea turtle) to a significantly reduced fauna most likely as the result of overexploitation and possibly even local extirpation of certain taxa. For example, Scombridae (tuna family), Caranx sp. and C. latus, all typically ranked as high-level predators, are present in the earlier level but absent in both later levels. This finding is in line with Wing \& Wing's (2001) observation of decline in abundance of predatory fishes on several Caribbean island sites since predators are more susceptible to overfishing compared to reef herbivores (Wing, 2001). Also present in the earlier Level 3 but missing from the later two levels are the herbivorous reef fishes $S$. rubripinne, Acanthurus sp., and A. coeruleus, most likely captured with traps. Typically, in a situation in which the predatory taxa are removed from the ecosystem, herbivores and omnivores flourish and increase in number (Wing, deFrance, \& Kozuch, 2002). The demonstrated decline in size for $S$. viride, another obligate reef dweller, indicates that growth overfishing, or at a minimum fishing pressure, was being exerted on Scaridae and likely other reef dwelling taxa. This type of stress might explain the absence of S. rubripinne and the Acanthuridae from the later deposits at the Minnis-Ward site. Overall, Caranx sp., C. latus, S. rubripinne, Acanthurus sp., A. coeruleus, Scombridae, and Aves characterize the earlier pre-Columbian fauna at Minnis-Ward while absent in the later pre-Columbian levels. While some of this variation could be due to sampling error from level to level, the general pattern of declining biodiversity over time is striking indeed.

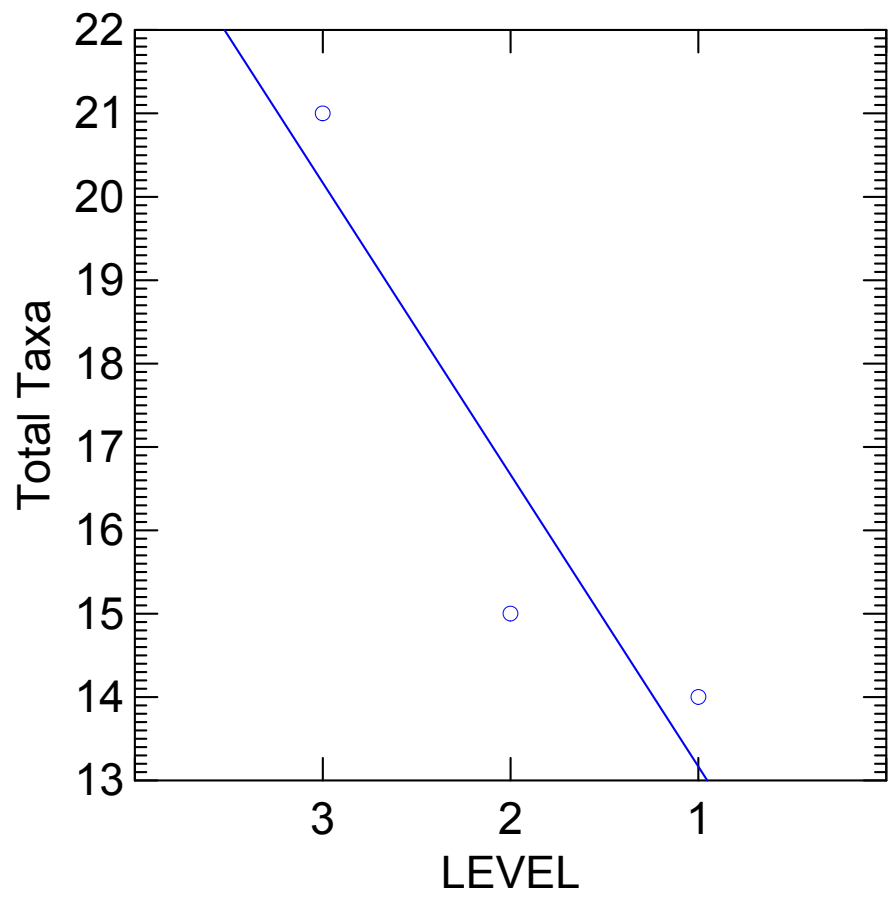

Fig. 11. Total number of identified vertebrate taxa at the Minnis-Ward site declines dramatically from 21 total taxa in Level 3 to 14 taxa in Level 1, indicative of a decline in biodiversity over time, ca. A.D. $880-1490(n=50, p<0.001$, least squares line: $y=-3.50 x+$ 9.67). Open circles represent individual identified taxa. 
The observable decline in average trophic level from Level 3 to Level 1 at Minnis-Ward mirrors that found by Wing (2001) and Wing \& Wing (2001) for five Caribbean islands including Nevis, Puerto Rico, Saba, St. Martin, and St. Thomas during the period ca. A.D. 100-1390. Although the method utilized for the purposes of this chapter is not the same as that used by Wing (albeit modeled upon her work), the fact that similar results were obtained is encouraging and significant. The general hypothesis explaining declining trophic levels in fish catches over time is that high trophic level taxa - the predatorial, carnivorous fishes (in this case, represented by Caranx sp. and C. latus) are targeted and eventually extirpated first, followed by a shift to, or greater emphasis upon, lower trophic level taxa (in this case, represented primarily by the herbivorous and varied Scaridae) (see Pauly et al., 1998). According to Wing (2001:123), “Analysis of mean trophic levels is a way of examining these and other changes in marine organisms in the sites;" she goes on to note that in her study of five island archaeological sites, "Without exception the mean trophic levels of reef fishes declines [sic] in the later deposits." Explaining these changes for the Tutu site on St. Thomas, Wing, deFrance, \& Kozuch (2002:165) describe the mechanism driving declining trophic levels: "Overexploitation at the top of the food chain reduces this segment of the fauna.... This allows the populations of species at lower trophic levels to ... become more available for further human exploitation." Although referring to contemporary fisheries landings, Pauly et al. (1998:860) note that, "Fishing down food webs (that is, at lower trophic levels) leads at first to increasing catches, then to a phase transition associated with stagnating or declining catches. These results indicate that [these] exploitation patterns are unsustainable." The concept of sustainability will be revisited in the Conclusions.

Related to declining biodiversity and declining average trophic level is another observable trend in the faunal materials from the Minnis-Ward site: a change in the coral reef community composition over time. The primary notable changes are the absences of the Carangidae, S. rubripinne, and the Acanthuridae in the two later levels. Change in community composition is generally taken to represent the result of human exploitation that typically targets apex predators first (Baum et al., 2003; Caddy et al., 1998; Conover \& Munch, 2002; Hawkins \& Roberts, 2004; Jackson et al., 2001; Wing, 2001). Depletion of predatory species (such as groupers, jacks, etc.) then causes a cascade effect, altering community composition as a result of harvesting practices that eventually switch to lower level feeders in the absence of carnivores (Coleman et al., 2004; Hawkins \& Roberts, 2004; Jackson et al., 2001; Mumby et al., 2006; Pandolfi et al., 2003; Pauly, Froese, \& Christensen, 1998; Pauly et al., 1998; Wing, 2001; Wing, deFrance, \& Kozuch, 2002); this phenomenon is generally referred to as "fishing down the marine food web" (Pauly et al., 1998). Coleman et al. (2004:1959) report that, "Commercial and recreational fishing have similar demographic and ecological effects on fished populations. They truncate size and age structures, reduce biomass, and alter community composition. ... All these fishery removals can cause cascading trophic effects that alter the structure, function, and productivity of marine ecosystems." Hawkins \& Roberts (2004:15), in their study of fishing pressure on six Caribbean islands, have shown that, "intensive artisanal fishing has transformed Caribbean reefs" (Hawkins \& Roberts, 2004:215) by targeting larger-bodied individuals, reducing fishery biomass, and causing cascading effects and eventual depletion and reduction in size of predatory groupers, snappers, and reef herbivores - especially parrotfishes. This appears to be what happened in the case of the Minnis-Ward vertebrate fauna (composed mostly of 
fishes). The findings of Hawkins \& Roberts (2004:225) indicate that, "[modern] artisanal fisheries have transformed coral reefs in ways that seriously compromise their ecological and economic value." It would appear, based upon the evidence presented above, that the same was true for the prehistoric subsistence fishery of the Lucayans on San Salvador.

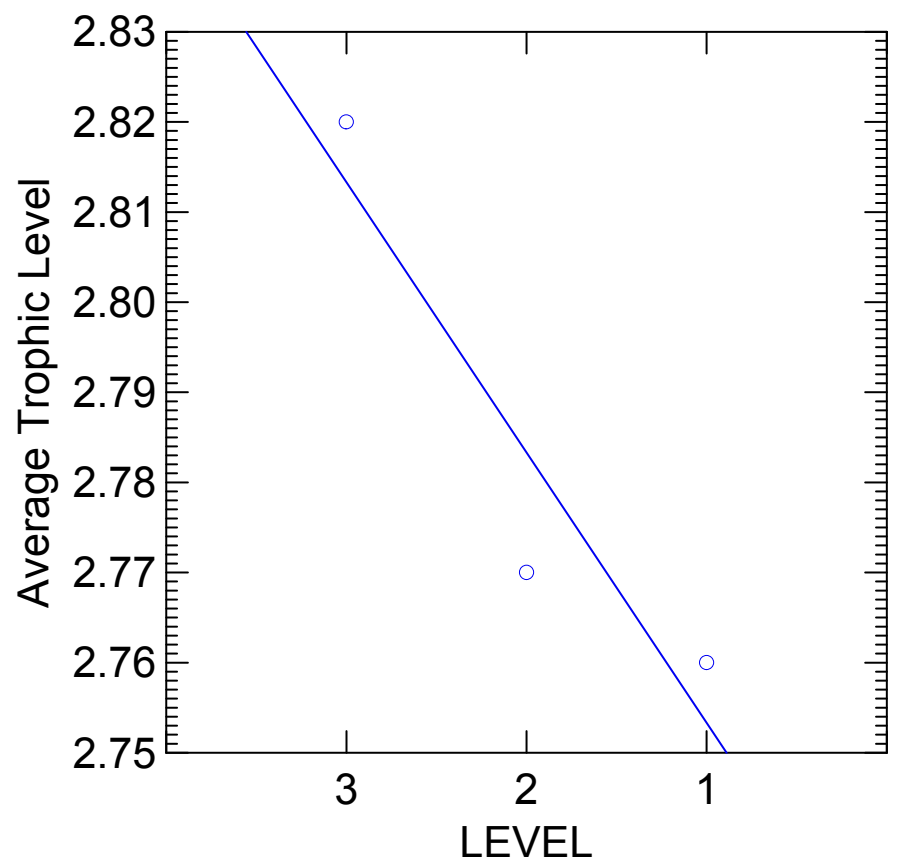

Fig. 12. Average trophic level at the Minnis-Ward site declines notably from a mean of 2.819 in Level 3 to 2.760 in Level 1, indicative of fishing down the marine food web over time, ca. A.D. $880-1490(n=50, p<0.001$, least squares line: $y=-2.95 x+2.72)$. Open circles represent individual trophic levels calculated for each stratigraphic level.

Finally, some last words should be said about the possible effects of climate change on the trends observed in the invertebrate and vertebrate fauna at both the Minnis-Ward and North Storr's Lake sites. It should be noted that the time period represented by the various archaeological levels reported herein, ca. A.D. 900-1500, marks a time of major transition between two widely recognized global climate phenomena: the Medieval Warm Period (MWP), ca. A.D. 800-1250, and the Little Ice Age (LIA), ca. A.D. 1300-1850 (Archer, 2007; Broecker, 2001; Cook et al., 2004; Cronin, 1999; deMenocal et al., 2000; Fagan, 2000, 2004; Goudie, 1992; Hardy, 2003; Keigwin, 1996; Osborn \& Briffa, 2006; Sridhar et al., 2006; R. Wilson, Drury, \& Chapman, 2000). At the time of the MWP, sea surface temperatures (SSTs) are recorded as being ca. $1^{\circ} \mathrm{C}$ warmer than today, while during the LIA SSTs were ca. $1^{\circ} \mathrm{C}$ cooler than today (Keigwin, 1996). In fact, based on a study of archaeological Codakia orbicularis (Linnaeus, 1758) (tiger lucine) dated to A.D. 1440-1530 (calibrated) from the Pigeon Creek site on San Salvador, nearby Pigeon Creek winter surface temperatures are estimated to have been $1.65-2.33^{\circ} \mathrm{C}$ cooler than at present (Cerajewski, 2002). Clearly, cooler SSTs in an otherwise semi-tropical region would likely have a negative effect on fisheries 
richness and abundance. For example, the Atlantic cod fishery declined notably during the late LIA due to colder temperatures and resulting lower productivity (Rose, 2004). Whether a shift to a slightly cooler climate can explain the decline in the terrestrial Gecarcinidae as well as the decline in average trophic level (which would suggest that higher level fishes were somehow affected disproportionately compared to lower level feeders) seems doubtful. It is asserted that the declines in weights, sizes, number of identified taxa, and trophic levels that have been described in this research are most parsimoniously attributed to human predation and overexploitation of the various resources under consideration (Carlson, 1999; Carlson \& Keegan, 2004; Keegan, Portell, \& Slapcinsky, 2003; Newsom \& Wing, 2004; Quitmyer, 2003; Wing, 2001; Wing, deFrance, \& Kozuch, 2002; Wing \& Wing, 2001).

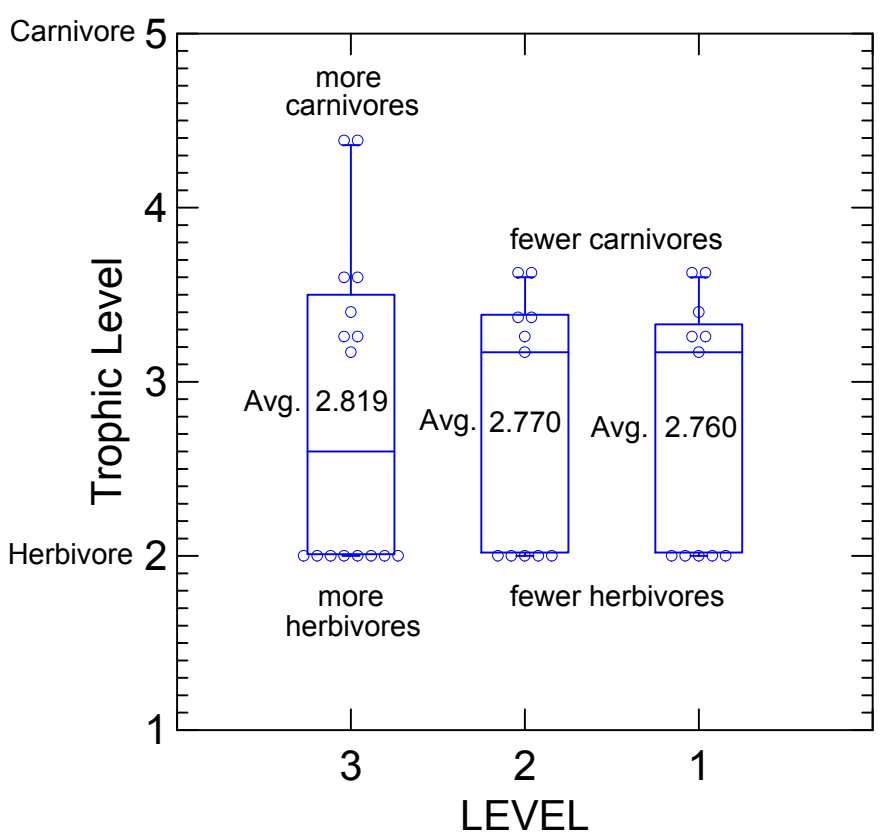

Fig. 13. Decline in average trophic level and alteration of community composition of marine vertebrate fauna at the Minnis-Ward site (SS-3), A.D. 880-1490. Note that there are both more carnivores and more herbivores (trophic levels 5 and 2, respectively) in the earlier Level 3 compared to the later levels. Average trophic level is indicated numerically in the center of each box plot. Each of the box plots show average and median trophic level (horizontal line within box), interquartile range (box), and range (whiskers) for each stratigraphic level. Open circles represent individual identified marine taxa.

\section{Conclusions}

Confidence in the results presented above is bolstered by the fact that similar trends are apparent in multivariate datasets involving terrestrial (Gecarcinidae), intertidal (C. pica, 
Chiton tuberculatus/Acanthopleura granulata), and marine (S. viride and Serranidae) fauna from two different archaeological sites and slightly different time periods: the Minnis-Ward site (SS-3) dating to ca. A.D. 880-1490, and the North Storr's Lake site (SS-4) with deposits dating to ca. A.D. 1300-1520. Trends of decline in abundance and size of exploited resources appear to have occurred during both earlier (ca. A.D. 900-1150) and later (ca. A.D. 13001490) pre-Columbian periods on San Salvador, regardless of the length of duration of the deposits (ca. 600 years for Minnis-Ward and ca. 200 years for North Storr's Lake). These trends involve declines in abundance (as measured by weight in g), declines in sizes (as measured in $\mathrm{mm}$ on key skeletal elements), and declines in number of identified taxa (reflecting declining biodiversity) and trophic levels (reflecting the elimination of higher level feeders and alteration of community composition) across time as recorded in the various archaeological levels of the two sites. The reliability of the present research is verified by the fact that other scholars have recorded analogous findings using similar techniques on multiple Caribbean islands on deposits ranging in age from ca. 500 B.C.-A.D. 1500. In the words of Worm et al. (2006:787), "when the available experimental data are combined, they reveal a strikingly general picture" - and that is a picture of prehistoric overexploitation of terrestrial and intertidal resources, such as land crabs and various mollusks, and overfishing of marine coral reef dwellers such as Scaridae and Serranidae.

This brings us to the issue of sustainability, particularly regarding the sustainability and maximum sustainable yield (MSY) of coastal and maritime organisms. Sustainability refers to the idea that an "activity can be maintained without exhaustion or collapse" (Harper, 2004:276). Another widely accepted definition of sustainability is that an activity "meets the needs of the present without compromising the ability of future generations to meet their own needs" (World Commission on Environment and Development, 1987). MSY is often defined as "maximum use that a renewable resource can sustain without impairing its renewability through natural growth or replenishment" (European Environment Agency, 2006). Equipped with the above definitions, and based on the evidence at hand, it is now possible to answer the question, "Did the Lucayans of San Salvador practice sustainable harvesting/fishing practices?" The answer would appear to be "No." Lucayan harvesting of land crabs, intertidal mollusks, and fishes in the nearby coral reefs appears to have resulted minimally in the exhaustion of the resources under consideration. By over-harvesting and fishing down the local marine food web, Lucayans were engaging in opportunistic subsistence practices that, in our opinion, would have eventually compromised the ability of future generations to meet their needs (this lifestyle was put to a premature end with the arrival of Columbus and subsequent Spanish slave raiders who exterminated the Lucayans between 1492 and 1513; see Sauer, 1966). It is also clear that the Lucayans did not practice MSY since the evidence suggests that they were engaged in growth overfishing of certain marine organisms including $S$. viride and certain Serranidae. Continuation of these harvesting and fishing practices certainly would have impaired the renewability of terrestrial, intertidal, and local marine (coral reef) ecosystems due to the interruption of natural growth and replenishment processes by Lucayan subsistence practices.

It should be noted that the prehistoric Lucayan population of San Salvador is estimated to have been relatively low - in the range of 500-1000 people (Blick, 2011b; Kelley, 1992), 
although some scholars (based upon erroneous extrapolations of the data, in our opinion) argue for a much larger total population of 2250 with a range of 1000-4400 people (Pickering, 1997). Based upon the number of archaeological sites on San Salvador and throughout the Bahamas per square kilometer of land area (Keegan, 1992, 1997), the total population of the Bahamas is estimated to have been ca. 46,800-87,750 (Blick, 2011b), a range that corresponds well with Spanish conquest documents (Craton \& Saunders, 1992; Pickering, 1997; Sauer, 1966). Based on our calculations, the total population of San Salvador (land area ca. $101 \mathrm{~km}^{2}$, total area $163 \mathrm{~km}^{2}$ ) would have been ca. $535-1008$ people (Blick, 2011b) with a population density of ca. 5.30-9.98 per $\mathrm{km}^{2}$. This estimated prehistoric population range is near the modern fluctuating population of San Salvador, 465-970 people (White, 1985; see also Government of the Bahamas, 2005), suggesting some sort of upper limit for the carrying capacity of the island. The prehistoric Minnis-Ward site probably contained some 15-18 houses (Blick, 2003, 2004) with an estimated population of ca. 120-144 people (at 8 persons per ordinary house; see Ramcharan 2004:8384, Table 5.3). According to Columbus' Diario, villages were small in the Bahamian Archipelago with some 120-225 people living in approximately 12-15 houses per village (Dunn \& Kelley, 1989; Rouse, 1992). The late Lucayan village at North Storr's Lake was probably similar in size. All of these figures suggest that the environmental impact recorded in the faunal remains of pre-Columbian San Salvador was likely caused by a relatively small human population with a low, hunter-gatherer/horticulturalist type population density.

The evidence presented in this chapter indicates that relatively minor, low density human populations can have significant environmental impacts, especially on small, vulnerable island ecosystems. In the words of Quitmyer (2003:131-132), "Island ecosystems are particularly fragile and susceptible to human disturbances because their biological reservoirs are small and not easily replenished. ... human contact, even at very low levels of cultural complexity, can degrade the environment ... The most dramatic evidence appears in the faunal records of island midden deposits" (the subjects of the excavations at the Minnis-Ward and North Storr's Lake archaeological sites). Although once considered "Ecological Indians" (Krech, 1999), it has become clear that even small indigenous populations have had serious impacts on their local environments via horticultural and animal exploitation practices (Redman, 1999). The findings presented in this chapter have major implications regarding the sustainability of fisheries, the effect of human population size and resource pressure, and human-induced environmental impacts in the past, present, and future.

\section{Acknowledgments}

The generosity of the Dr. Donald T. and Kathy D. Gerace Foundation is recognized for its support for students and assistants and for general support for work at the Minnis-Ward and North Storr's Lake sites from 2003-2010 (Figure 14). The Bahamian Antiquities, Monuments and Museums Corporation is thanked for its permission to analyze vertebrate faunal remains and radiocarbon samples from Minnis-Ward and North Storr's Lake. This research was made possible by the Georgia College \& State University International Studies office and 2003-2010 Faculty Development Funds through the Department of Government \& 
Sociology at Georgia College \& State University. Supplies and equipment used in this research were provided by funds through a 2003 Faculty Research Grant from Georgia College \& State University, a 2004 Dean's Award from the Dean of the School of Liberal Arts \& Sciences at GC\&SU, and by a 2004 Council on Undergraduate Research grant to Jeffrey P. Blick and David Brinson. Dr. Doug Dvoracek of University of Georgia's Center for Applied Isotope Studies is much appreciated for facilitating the processing of AMS radiocarbon dates. Funding for radiocarbon dating was provided by a 2006 Faculty Research Grant to Jeffrey P. Blick from Georgia College \& State University. An abbreviated version of a similar paper appeared in the Journal for Nature Conservation (Blick, 2007).

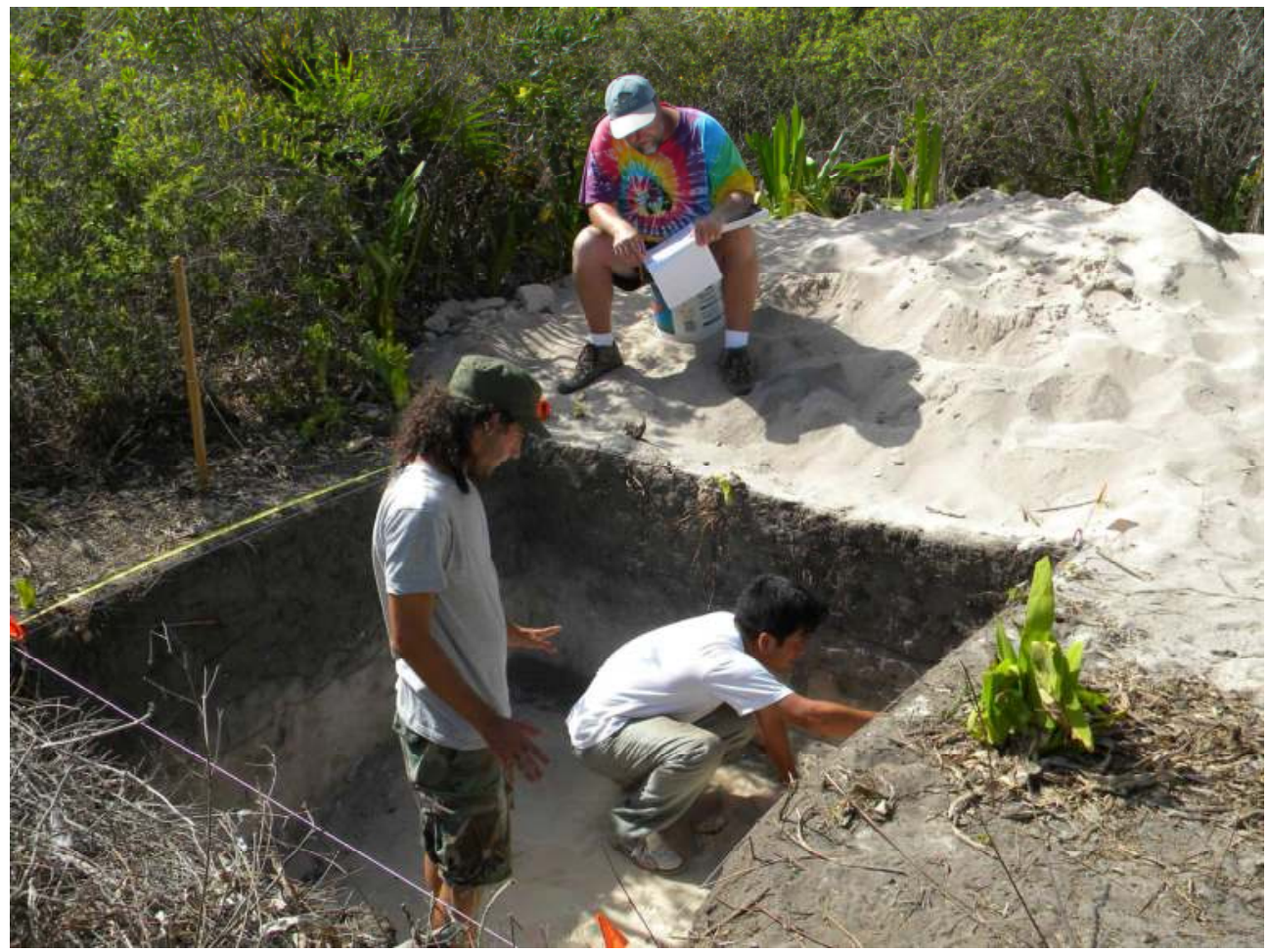

Fig. 14. Archaeological fieldwork at the Minnis-Ward site (SS-3), June 2010, San Salvador, Bahamas. Dr. Blick instructs students in the drawing of a soil profile.

\section{References}

Albury, P. (1975). The Story of the Bahamas, Macmillan Caribbean, ISBN 978-0333171325, London

Archer, D. (2007). Global Warming: Understanding the Forecast, Blackwell, ISBN 9781405140393, Malden 
Bahn, P., \& Flenley, J. (1992). Easter Island, Earth Island, Thames \& Hudson, ISBN 9780500050651, New York

Baum, J.K., Myers, R.A., Kehler, D.G., Worm, B., Harley, S.J., \& Doherty, P.A. (2003). Collapse and Conservation of Shark Populations in the Northwest Atlantic, Science, 299, pp. 389-392, ISSN 0036-8075

Bellwood, D.R. (1994). A Phylogenetic Study of the Parrotfishes, Family Scaridae (Pisces: Labroidei), with a Revision of Genera. Records of the Australian Museum, Suppl. 20, pp. 1-86, Australian Museum, ISBN 0731036638, Sydney

Berman, M.J. (1999). Wooden Artifacts from the Deadman's Reef Site (GB4), Grand Bahama, Commonwealth of the Bahamas, Report of Investigations to the National Geographic Society, Scientific Research Grant 6374-98, Permission to Cite Granted by the Author

Berman, M.J., \& Gnivecki, P.L. (1995). Colonization of the Bahama Archipelago: A Reappraisal, World Archaeology, 26, 3, pp. 421-441, ISSN 0043-8243

Berman, M.J., \& Pearsall, D. (2000). Plants, People, and Culture in the Prehistoric Central Bahamas: A View from the Three Dog Site, an Early Lucayan Settlement on San Salvador Island, Bahamas, Latin American Antiquity, 11, 3, pp. 219-239, ISSN 10456635

Berman, M.J., \& Pearsall, D.M. (2005). At the Crossroads: The Role of Starch Grain Analysis in Lucayan Prehistory, Paper Presented at the 11 th Symposium on the Natural History of the Bahamas, Gerace Research Centre, San Salvador, June 2005

Berman, M.J., \& Pearsall, D.M. (2008). At the Crossroads: Starch Grain and Phytolith Analyses in Lucayan Prehistory, Latin American Antiquity, 19, 2, pp. 181-203, ISSN 1045-6635

Bjorndal, K.A., \& Jackson, J.B.C. (2003). Roles of Sea Turtles in Marine Ecosystems: Reconstructing the Past, In: The Biology of Sea Turtles, Volume II, P.L. Lutz, J.A. Musick, \& J. Wyneken, (Eds.), pp. 259-273, CRC Press, ISBN 978-0849311239, Boca Raton

Blick, J.P. (2003). Systematic Shovel Testing at the Minnis-Ward site (SS-3), San Salvador, Bahamas: Archaeological Evidence for Pre-Columbian Households and Subsistence Patterns, Preliminary Report Presented to the Gerace Research Centre, San Salvador, Bahamas

Blick, J.P. (2004). Report on the 2004 Archaeological Investigations at Barker's Point (SS-15, SS-37) and Minnis-Ward (SS-3), San Salvador, Bahamas, with Commentary on the Nature of Fire-Cracked Rock, Preliminary Report Presented to the Gerace Research Centre, San Salvador, Bahamas

Blick, J.P. (2006). Recent Archaeological and Paleoecological Investigations on San Salvador: Evidence for Pre-Columbian Impact on Terrestrial and Marine Resources in the Bahamas, Paper Presented at the International Council for Archaeozoology (ICAZ), Mexico City, Mexico, August 2006

Blick, J.P. (2007). Pre-Columbian Impact on Terrestrial, Intertidal, and Marine Resources, San Salvador, Bahamas (A.D. 950-1500), Journal for Nature Conservation, 15, 3, pp. 174-183, ISSN 1617-1381 
Blick, J.P. (2011a). The Case for San Salvador as the Site of the 1492 Columbus Landfall: Principles of Historical Archaeology Applied to the Current Evidence, Paper Presented at the $14^{\text {th }}$ Symposium on the Natural History of the Bahamas, Gerace Research Centre, San Salvador, Bahamas, June 2011

Blick, Jeffrey P. (2011b). Paleodemographic Reconstruction of the Pre-Columbian Population of Guanahaní (San Salvador, Bahamas). In: Proceedings of the Thirteenth Symposium on the Natural History of the Bahamas, J. Baxter and E. Cole, (Eds.), pp. 200-212, Gerace Research Centre, San Salvador, Bahamas

Blick, J.P., \& Dvoracek, D. (2011). Forty New Radiocarbon Dates from Recent Archaeological Research on San Salvador, Bahamas: Implications for Island Chronology and Settlement, Paper Presented at the 14 ${ }^{\text {th }}$ Symposium on the Natural History of the Bahamas, Gerace Research Centre, San Salvador, Bahamas, June 2011

Blick, J.P., \& Kjellmark, E. (2006). Recent Archaeological and Paleoecological Investigations in the Bahamas: Evidence for Pre-Columbian Impact on the Environment, Paper Presented at the 83rd Annual Meeting of the Georgia Academy of Science, Georgia Perimeter College, Atlanta, March 2006

Blick, J.P., \& Murphy, B. (2005). Report on the 2005 Archaeological Investigations at the North Storr's Lake Site (SS-4), San Salvador,Bahamas (Preliminary Report, $2^{\text {nd }}$ edition), Preliminary Report Presented to the Gerace Research Centre, San Salvador

Blick J.P., Creighton, A., \& Murphy, B. (2006). Report on the 2006 Archaeological Investigations at the North Storr's Lake Site (SS-4), San Salvador, Bahamas: Stratigraphic Excavations and the Role of the Sea Turtle in Lucayan Subsistence (Preliminary Report, Revised), Preliminary Report Presented to the Gerace Research Centre, San Salvador, Bahamas

Blick, J.P., Hopkins, J.H., \& Oetter, D. (2011). The Prehistoric Settlement Pattern of San Salvador, Bahamas, Journal of Island and Coastal Archaeology 6, 3, pp. 421-441, ISSN 1556-4894

Blick, J.P., Jackson, C.C., Thacker, F.O, \& Pittman, J.M. 2009. Archaeological Excavations at the Minnis-Ward Site (SS-3), and the Discovery of the Mary Ann Blick Site (SS-41), MayJune 2009, Research Report Presented to the Gerace Research Centre, San Salvador, Bahamas, Georgia College \& State University, Milledgeville

Brill, R.H., \& Hoffman, C.A. (1985). Some Glass Beads Excavated on San Salvador Island in the Bahamas, Annales du 10e Congrěs de l'Association Internationale pour l'Histoire $d u$ Verre, Madrid-Segovia, September 1985, pp. 373-400

Brill, R.H., Barnes, I.L., Tong, S.S.C., Joel, E.C., \& Murtaugh, M.J. (1987). Laboratory Studies of Some European Artifacts Excavated on San Salvador Island, In: Columbus and His World, D.T. Gerace, (Ed.), pp. 247-292, Bahamian Field Station, ISBN 9780935909234, San Salvador

Broecker, W.S. (2001). Paleoclimate: Was the Medieval Warm Period Global?, Science, 291, pp. 1497-1499, ISSN 0036-8075

Burney, D.A. (1997). Tropical Islands as Paleoecological Laboratories: Gauging the Consequences of Human Arrival, Human Ecology, 25, 3, pp. 437-457, ISSN 14026902 
Caddy, J.F., Csirke, J., Garcia, S.M., \& Grainger, R.J.R. (1998). How Pervasive is “Fishing Down Marine Food Webs"?, Technical Comments, Science, 282, p. 1383a, ISSN 0036-8075

Carder, N., Reitz, E.J, \& Crock, J. (2007). Fish Communities and Populations During the Post-Saladoid Period (AD 600/800-1500), Anguilla, Lesser Antilles, Journal of Archaeological Science, 34, pp. 588-599, ISSN: 0305-4403

Carlson, L.A. (1999). Aftermath of a Feast: Human Colonization of the Southern Bahamian Archipelago and its Effect on the Indigenous Fauna, Ph.D. thesis, University of Florida

Carlson, L.A. \& Keegan, W.F. (2004). Resource Depletion in the Prehistoric Northern West Indies, In: Voyages of Discovery: The Archaeology of Islands, S.M. Fitzpatrick, (Ed.), pp. 85-107, Praeger, ISBN 978-0275979478, Westport

Cerajewski, R.J. (2002). Paleoclimate Reconstruction Using Isotopic Analysis of Tropical Bivalves from the Pigeon Creek Archaeological Site, San Salvador, Bahamas, Master's thesis, University of Georgia

Coleman, F.C., Figueira, W.F., Ueland, J.S., \& Crowder, L.B. (2004). The Impact of Recreational Fisheries on Marine Fish Populations, Science, 305, pp. 1958-1960, ISSN 0036-8075

Conover, D.O., \& Munch, S.B. (2002). Sustaining Fisheries Yields over Evolutionary Time Scales, Science, 297, pp. 94-96, ISSN 0036-8075

Cook, E.R., Woodhouse, C.A., Eakin, C.M., Meko, D.M., \& Stahle, D.W. (2004). Long-term Aridity Changes in the Western United States, Science, 306, pp. 1015-1018, ISSN 0036-8075

Craton, M., \& Saunders, G. (1992). Islanders in the Stream: A History of the Bahamian People, Volume I: From Aboriginal Times to the End of Slavery, University of Georgia Press, ISBN 978-0820321226, Athens

Cronin, T.M. (1999). Principles of Paleoclimatology, Columbia University Press, ISBN 9780231109550, New York

deMenocal, P., Ortiz, J., Guilderson, T., \& Sarnthein, M. (2000). Coherent High- and LowLatitude Climate Variability During the Holocene Warm Period, Science, 288, pp. 2198-2202, ISSN 0036-8075

Delvaux, T.R., Fry, G.F., \& Murphy, B. (2006). A Review of the Storr's Lake Site (SS4), San Salvador Island, Bahamas, 1996-2005, Paper Presented at the 71 ${ }^{\text {st }}$ Annual Meeting of the Society for American Archaeology, San Juan, Puerto Rico, April 2006

Diehl, F.A., Mellon, D., Garrett, R.H., \& Elliott, N. (1988). Field Guide to the Invertebrates of San Salvador Island, Bahamas, Bahamian Field Station, San Salvador

Dunn, O., \& Kelley, J.E. (1989). The Diario of Christopher Columbus's First Voyage to America, 1492-1493, University of Oklahoma Press, ISBN 978-0806123844, Norman

Estes, J.A., Terborgh, J., Brashares, J.S., Power, M.E., Berger, J., Bond, W.J., Carpenter, S.R., Essington, T.E., Holt, R.D., Jackson, J.B.C., Marquis, R.J., Oksanen, L., Oksanen, T., Paine, R.T., Pikitch, E.K., Ripple, W.J., Sandin, S.A., Scheffer, M., Schoener, T.W., Shurin, J.B., Sinclair, A.R.E., Soulé, M.E., Virtanen, R., \& Wardle, D.A. (2011). Trophic Downgrading of Planet Earth, Science, 333, 6040, pp. 301-306, ISSN 00368075 
Erlandson, J.M., \& Fitzpatrick, S.M. (2006). Oceans, Islands, and Coasts: Current Perspectives on the Role of the Sea in Human Prehistory, Journal of Island and Coastal Archaeology, 1, pp. 5-32, ISSN: 1556-4894

European Environment Agency. (2006). EEA Glossary, Date of Access 29 July 2011, Available from: http://glossary.eea.europa.eu/terminology/concept_html?term=maximum\% 20sustainable\%20yield

Fagan, B.M. (2000). The Little Ice Age: How Climate Made History (1300-1850), Basic Books, ISBN 978-0465022724, New York

Fagan, B.M. (2004). The Long Summer: How Climate Changed Civilization, Basic Books, ISBN 978-0465022823, New York

Frank, K.T., Petrie, B., Choi, J.S., \& Leggett, W.C. (2005). Trophic Cascades in a Formerly Cod-Dominated Ecosystem, Science, 308, 5728, pp. 1621-1623, ISSN 0036-8075

Froese, R., \& Pauly, D., (Eds.). (2005). Fish Base, Date of Access 28 July 2011, Available from: http://www.fishbase.org/

Goodwin, R.C. (1980). Demographic Change and the Crab-Shell Dichotomy, Proceedings of the $8^{\text {th }}$ International Congress for the Study of Pre-Columbian Cultures of the Lesser Antilles, pp. 45-68

GoogleEarth. (2006). GoogleEarth: A 3D Interface to the Planet. Date of Access 28 July 2011, Available from: www.earth.google.com/

Goudie, A. (1992). Environmental Change (3rd edition), Clarendon Press, ISBN 0198741677, Oxford

Government of the Bahamas. (2005). Population in Islands, Census Years 1970-2000, Date of Access 26 April 2005, Available from: www.bahamas.gov.bs/bahamasweb2/ home.nsf/vContentW/9C7DE759B 4AEFBEA06256ED1

Granberry, J., \& Vescelius, G. (2004). Languages of the Pre-Columbian Antilles, University of Alabama Press, ISBN 978-0817351236, Tuscaloosa

Hardy, J.T. (2003). Climate Change: Causes, Effects, and Solutions, Wiley, ISBN 978-0470850183, Chichester

Harper, C.L. (2004). Environment and Society: Human Perspectives on Environmental Issues (3rd edition), Pearson/Prentice Hall, ISBN 978-0131113411, Upper Saddle River

Hawkins, J.P., \& Roberts, C.M. (2004). Effects of Artisanal Fishing on Caribbean Coral Reefs, Conservation Biology, 18, pp. 215-226, ISSN 0888-8892

Hill, K. (2001). Cardisoma guanhumi, Smithsonian Marine Station at Fort Pierce, Date of Access 28 July 2011, Available from: www. sms.si.edu/irlspec/Cardis_guanhu.htm

Hoffman, C.A. (1967). Bahama Prehistory: Cultural Adaptation to an Island Environment, Ph.D. thesis, University of Arizona

Hoffman, C.A. (1987). Archaeological Investigations at the Long Bay Site, San Salvador, Bahamas, In: Columbus and His World, D.T. Gerace, (Ed.), pp. 237-245, Bahamian Field Station, ISBN 978-0935909234, San Salvador

Hopkins, J.H., Oetter, D. \& Blick, J.P. (2011). Analysis of Prehistoric Settlement Patterns on San Salvador, Bahamas, Using the San Salvador GIS Database. In: Proceedings of the Thirteenth Symposium on the Natural History of the Bahamas, J. Baxter and E. Cole, (Eds.), pp. 213-228. Gerace Research Centre, San Salvador, Bahamas

Jackson, J.B.C., Kirby, M.X., Berger, W. H., Bjorndal, K.A., Botsford, L.W., Bourque, B.J., Bradbury, R.H., Cooke, R., Erlandson, J., Estes, J.A., Hughes, T.P., Kidwell, S., 
Lange, C.B., Lenihan, H.S., Pandolfi, J.M., Peterson, C.H., Steneck, R.S., Tegner, M.J., \& Warner, R.R. (2001), Historical Overfishing and the Recent Collapse of Coastal Ecosystems, Science, 293, pp. 629-638, ISSN 0036-8075

Johnson, K.R. (1980). Results of Tests to Determine Mineralogy of an Artifact from San Salvador, Bahamas, Bahamas Archaeological Project Reports and Papers 1980, CCFL Bahamian Field Station, San Salvador

Jones, A.R. (1985). Dietary Change and Human Population at Indian Creek, Antigua, American Antiquity, 50, 3, pp. 518-536, ISSN 0002-7316

Keegan, W.F. (1986). The Ecology of Lucayan Arawak Fishing Practices, American Antiquity, 51, 4, pp. 816-825, ISSN 0002-7316

Keegan, W.F. (1992). The People Who Discovered Columbus: The Prehistory of the Bahamas, University Press of Florida, ISBN 978-0813011370, Gainesville

Keegan, W.F. (1997). Bahamian Archaeology: Life in the Bahamas and Turks and Caicos Before Columbus, Media Publishing, ISBN 978-9768170033, Nassau

Keegan, W.F., Portell, R.W., \& Slapcinsky, J. (2003). Changes in Invertebrate Taxa at Two Pre-Columbian Sites in Southwestern Jamaica, AD 800-1500, Journal of Archaeological Science, 30, pp. 1607-1617, ISSN 0305- 4403

Keigwin, L.D. (1996). The Little Ice Age and Medieval Warm Period in the Sargasso Sea, Science, 274, pp. 1504-1508, ISSN 0036-8075

Kelley, J.E. (1992). Epistemology 101 for Landfall Students: An Appreciation of an Important New Book, Terrae Incognitae, 24, pp. 101-110, ISSN 2040-8706

Kjellmark, E. (1996). Late Holocene Climate Change and Human Disturbance on Andros Island, Bahamas, Journal of Paleolimnology, 15, pp. 133-145, ISSN 0921-2728

Krech, S. (1999). The Ecological Indian: Myth and History, W.W. Norton, ISBN 978-0393321005, New York

LaPilusa, T. \& J.S. Heilveil. (2011). Genetic Diversity of the Blue Land Crab, Cardisoma guanhumi Latreille (Crustacea: Decapoda), on Andros Island: Implications for Sustainable Management, Paper Presented at the $14^{\text {th }}$ Symposium on the Natural History of the Bahamas, Gerace Research Centre, San Salvador, Bahamas, June 2011

Lawson, B. (1993). Shelling San Sal: An Illustrated Guide to Common Shells of San Salvador Island, Bahamas, Bahamian Field Station, San Salvador

Morales, A., \& Rosenlund, K. (1979). Fish Bone Measurements: An Attempt to Standardize the Measuring of Fish Bones from Archaeological Sites, Steenstrupia, Copenhagen

Mumby, P.J., Dahlgren, C.P., Harborne, A.R., Kappel, C.V., Micheli, F., Brumbaugh, D.R., Holmes, K.E., Mendes, J.M., Broad, K., Sanchirico, J.N., Buch, K., Box, S., Stoffle, R.W., \& Gill, A.B. (2006). Fishing, Trophic Cascades, and the Process of Grazing on Coral Reefs, Science, 311, pp. 98-101, ISSN 0036-8075

Myers, R.A., Barrowman, N.J., Hutchings, J.A., \& Rosenberg, A.A. (1995). Population Dynamics of Exploited Fish Stocks at Low Population Levels, Science, 269, pp. 11061108, ISSN 0036-8075

Nelson, J.S., Cromman, E.J., Espinosa-Pérez, H., Findley, L.T., Gilbert, C.R., Lea, R.N., \& Williams, J.D. (2004). Common and Scientific Names of Fishes from the United States, Canada, and Mexico (6th edition), American Fisheries Society Special Publication 29, American Fisheries Society, ISBN 978-1888569612, Bethesda 
Newsom, L.A. \& Wing, E.S. (2004). On Land and Sea: Native American Uses of Biological Resources in the West Indies, University of Alabama Press, ISBN 978-0817313159, Tuscaloosa

Obregón, M. (1987). Columbus' First Landfall: San Salvador, In: Columbus and His World, D.T. Gerace, (Ed.), pp. 185-195, Bahamian Field Station, ISBN 978-0935909234, San Salvador

Obregón, M. (1989). Columbus' First Landfall, Paper Presented at the Phileas Conference, Ft. Lauderdale, Date of Access 26 June 2009, Available from: http://muweb.millersville.edu/ columbus/data/soc/OBREGON1.SPK

Osborn, T.J., \& Briffa, K.R. (2006). The Spatial Extent of 20th-Century Warmth in the Context of the Past 1200 Years, Science, 311, pp. 841-844, ISSN 0036-8075

Ostrander, G.K., \& Brocksmith, R. (1997). The Fishes of San Salvador Island: The Bahamas, Oklahoma State University, ISBN 978-0935909647, Stillwater

Pandolfi, J.M., Bradbury, R.H., Sala, E., Hughes, T.P., Bjorndal, K.A., Cooke, R.G., McArdle, D., McClenachan, L., M.J.H. Newman, Paredes, G., Warner, R.R., \& Jackson, J.B.C. (2003). Global Trajectories of the Long-Term Decline of Coral Reef Ecosystems, Science, 301, pp. 955-958, ISSN 0036-8075

Pauly, D., Christensen, V., Dalsgaard, J., Froese, R., \& Torres, F. (1998). Fishing Down Marine Food Webs, Science, 279, pp. 860-863, ISSN 0036-8075

Pauly, D., Froese, R., \& Christensen, V. (1998). Response to J.F. Caddy, et al. Science, 282, p. 1383a, ISSN 0036-8075

Pickering, K.A. (1997). The Population of Guanahani, Date of Access 28 July 2011, Available from: http://www.columbusnavigation.com/lclog4.shtml

Perry, L., Dickau, R., Zarrillo, S., Holst, I., Pearsall, D.M, Piperno, D., Berman, M.J., Cooke, R.G., Rademaker, K., Ranere, A.J., Raymond, J.S., Sandweiss, D.H, Scaramelli, F., Tarble, K., \& Zeidler, J. (2007). Starch Fossils and the Domestication and Dispersal of Chili Peppers (Capsicum spp. L.) in the Americas, Science, 315, pp. 986-988, ISSN 0036-8075

Quitmyer, I.R. (2003). Zooarchaeology of Cinnamon Bay, St. John, U.S. Virgin Islands: PreColumbian Overexploitation of Animal Resources, Bulletin of the Florida Museum of Natural History, 44, 1, pp. 131-158, ISSN 0071-6154

Rainey, F.G. (1940). Porto Rican Archaeology. Scientific Survey of Porto Rico and the Virgin Islands, 18, Pt. 1, New York Academy of Sciences, New York

Ramcharan, S. (2004). Caribbean Prehistoric Domestic Architecture: A Study of Spatio-Temporal Dynamics and Acculturation, Master's thesis, Florida State University

Redman, C.L. (1999). Human Impact on Ancient Environments, University of Arizona Press, ISBN 978-0816519637, Tucson

Reitz, E.J. (1994). Archaeology of Trants, Montserrat, Part 2: Vertebrate Fauna, Annals of the Carnegie Museum, 63, 4, pp. 297-317, ISSN 0097-4463

Reitz, E.J., \& Wing, E.S. (1999). Zooarchaeology, Cambridge University Press, ISBN 9780521485296, Cambridge

Robertson, R. (2003). The Edible West Indian "Whelk" Cittarium pica (Gastropoda: Trochidae): Natural History with New Observations, Proceedings of the Academy of Natural Sciences of Philadelphia, 153, 1, pp. 27-47, ISSN 0097-3157 
Rose, G.A. (2004). Reconciling Overfishing and Climate Change with Stock Dynamics of Atlantic Cod (Gadus morhua) over 500 Years, Canadian Journal of Fisheries and Aquatic Sciences, 61, pp. 1553-1557, ISSN 0706-652X

Rouse, I. (1992). The Tainos: Rise and Decline of the People Who Greeted Columbus, Yale University Press, ISBN 978-0300056969, New Haven

Russ, G.R. (1991). Coral Reef Fisheries: Side Effects and Yields, In: The Ecology of Fishes on Coral Reefs, P.F. Sale, (Ed.), pp. 601-635, Academic Press, ISBN 978-0126151817, San Diego

Sauer, C.O. (1966). The Early Spanish Main, University of California Press, ISBN 9780521088480 (reprint), Berkeley

Scudder, S.J., \& Quitmyer, I.R. (1998). Evaluation of Evidence for Pre-Columbian Human Occupation at Great Cave, Cayman Brac, Cayman Islands, Caribbean Journal of Science, 34, 1-2, pp. 41-49, ISSN 0008-6452

Serrand, N. (2002). Exploitation des Invertébrés Marins et Terrestres par les Populations Saladoïdes et post-Saladoïdes du Nord des Petites Antilles (500 B.C.-1200 A.D.): Etude de Cas et Comparaisons, Ph.D. thesis, Université Paris I Panthéon-Sorbonne

Shaklee, R., Fry, G., \& Delvaux, T. (2007). An Archaeological Report on the Storr's Lake Site, San Salvador: 1995-2005, Bahamas Naturalist and Journal of Science, 2, 1, pp. 31-39, ISSN 1819-4230

Sibert, J., Hampton, J., Kleiber, P., \& Maunder, M. (2006). Biomass, Size, and Trophic Status of Top Predators in the Pacific Ocean, Science, 314, pp. 1773-1776, ISSN 0036-8075

Sridhar, V., Loope, D.B., Swinehart, J.B., Mason, J.A., Oglesby, R.J., \& Rowe, C.M. (2006). Large Wind Shift on the Great Plains during the Medieval Warm Period, Science, 313, pp. 345-347, ISSN 0036-8075

Steadman, D.W. (1995). Prehistoric Extinctions of Pacific Island Birds: Biodiversity Meets Zooarchaeology, Science, 267, pp. 1123-1131, ISSN 0036-8075

Steadman, D.W., \& Stokes, A.V. (2002). Changing Exploitation of Terrestrial Vertebrates During the Past 3000 Years on Tobago, West Indies, Human Ecology, 30, 3, pp. 339367, ISSN 1402-6902

SPSS, Inc. 1997. SYSTAT Version 7.0 for Windows ${ }^{\circledR}$, Statistical Data Analysis Package, SPSS Inc., Chicago

Turgeon, D.D., Quinn, J.F., Jr., Bogan, A.E., Coan, E.V., Hochberg, F.G., Jr., Lyons, W.G., Mikkelsen, P.M., Neves, R.J., Roper, C.F.E., Rosenberg, G., Roth, B., Scheltema, A., Thompson, F.G., Vecchione M., \& Williams, J.D. (1998). Common and Scientific Names of Aquatic Invertebrates from The United States and Canada: Mollusks (2nd edition), American Fisheries Society Special Publication No. 26, American Fisheries Society, ISBN 1888569018, Bethesda

White, V. (1985). The Outermost Island: An Oral History of San Salvador, the Bahamas, Bahamian Field Station, ISBN 978-0935909197, San Salvador

Whyte, T.R., Berman, M.J., \& Gnivecki, P.L. (2005). Vertebrate Archaeofaunal Remains from the Pigeon Creek Site, San Salvador Island, the Bahamas, Proceedings of the $10^{\text {th }}$ Symposium on the Natural History of the Bahamas, Gerace Research Centre, San Salvador, June 2003, pp. 166-178 
Wilson, R.C.L., Drury, S.A., \& Chapman, J.L. (2000). The Great Ice Age: Climate Change and Life, Routledge, ISBN 978-0415198424, New York

Wilson, S.M. (1999). Cultural Pluralism and the Emergence of Complex Society in the Greater Antilles, Paper Presented at The 18th International Congress for Caribbean Archaeology, St. George's, Granada, Date of Access 28 July 2011, Available from: http://uts.cc.utexas.edu/ swilson/wilson_iaca99.html

Wing, E.S. (1969). Vertebrate Remains Excavated from San Salvador Island, Bahamas, Caribbean Journal of Science, 9, pp. 25-29, ISSN 0008-6452

Wing, E.S. (1989). Human Exploitation of Animal Resources in the Caribbean, In: Biogeography of the West Indies, C.A. Woods, (Ed.), pp. 137-152, Sandhill Crane Press, ISBN 978-1877743030, Boca Raton

Wing, E.S. (2001). The Sustainability of Resources Used by Native Americans on Four Caribbean Islands, International Journal of Osteoarchaeology, 11, pp. 112-126, ISSN 1047-482X

Wing, E.S., \& Reitz, E.J. (1982). Prehistoric Fishing Communities of the Caribbean, Journal of New World Archaeology, 5, 2, pp. 13-32, ISSN 0147-9024

Wing, E.S., \& Scudder, S.J. (1983). Animal Exploitation by People Living on a Tropical Marine Edge, In: Animals and Archaeology, C. Grigson \& J. Clutton-Brock, (Eds.), pp. 197-210, BAR International Series 183, Oxford, ISBN 0860542955, British Archaeological Reports

Wing, S.R., \& Wing, E.S. (2001). Prehistoric Fisheries in the Caribbean, Coral Reefs, 20, pp. 18, ISSN 0722-4028

Wing, E.S., deFrance, S.D., \& Kozuch, L. (2002). Faunal Remains from the Tutu Site, In: The Tutu Archaeological Village Site: A Multidisciplinary Case Study in Human Adaptation, E. Reich, (Ed.), pp. 141-165, Routledge, ISBN 978-0415239905, New York

Winter, J. (1980). A Preliminary Archaeological Survey of San Salvador, Bahamas, In: Bahamas Archaeological Project Reports and Papers 1980, D. Gerace (Ed.), pp. 1-3, Bahamian Field Station, San Salvador

Winter, J. (1981). 1981 Archaeological Site Reconnaissance: San Salvador, Cat Island, and Rum Cay, In: Bahamian Archaeology Project Reports and Papers 1981, D. Gerace, (Ed.), pp. 4-7, Bahamian Field Station, San Salvador

Winter, J. (1982). Reconnaissance of San Salvador, January 1982, In: Bahamas Archaeology Project Reports and Papers, D. Gerace, (Ed.), pp. 8-10, Bahamian Field Station, San Salvador

Winter, J. (1997). Ward/Minnis Site, Proceedings of the 17th International Association for Caribbean Archaeology, Radisson Cable Beach Resort, Nassau, July 2007, pp. 36-38

Winter, J. \& Gilstrap, M. (1991). Preliminary Results of Ceramic Analysis and Movements of Population into the Bahamas, Proceedings of the 12th International Congress for Caribbean Archaeology, pp. 371-386

Winter, J., \& Wing, E. (1995). A Refuse Midden at the Minnis Ward Site, San Salvador, Bahamas, Actas de XV Congreso Internacional de Arqueología del Caribe/Proceedings of the 15 th International Congress for Caribbean Archaeology, pp. 423-434

World Commission on Environment and Development. (1987). Our Common Future, Oxford University Press, ISBN 978-0192820808, Oxford 
Worm, B., Barbier, E.B., Beaumont, N., Duffy, J.E., Folke, C., Halpern, B.S., Jackson, J.B.C., Lotze, H.K., Micheli, F., Palumbi, S.R., Sala, E., Selkoe, K.A., Stachowicz, J.J., \& Watson, R. (2006). Impacts of Biodiversity Loss on Ocean Ecosystem Services, Science, 314, pp. 787-790, ISSN 0036-8075

Yesner, D.R. (1980). Maritime Hunter-Gatherers: Ecology and Prehistory, Current Anthropology, 21, 6, pp. 727-750, ISSN 0011-3204 


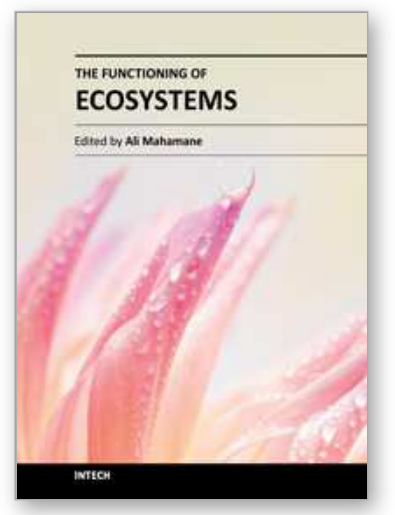

\author{
The Functioning of Ecosystems \\ Edited by Prof. Mahamane Ali
}

ISBN 978-953-51-0573-2

Hard cover, 332 pages

Publisher InTech

Published online 27, April, 2012

Published in print edition April, 2012

The ecosystems present a great diversity worldwide and use various functionalities according to ecologic regions. In this new context of variability and climatic changes, these ecosystems undergo notable modifications amplified by domestic uses of which it was subjected to. Indeed the ecosystems render diverse services to humanity from their composition and structure but the tolerable levels are unknown. The preservation of these ecosystemic services needs a clear understanding of their complexity. The role of the research is not only to characterise the ecosystems but also to clearly define the tolerable usage levels. Their characterisation proves to be important not only for the local populations that use it but also for the conservation of biodiversity. Hence, the measurement, management and protection of ecosystems need innovative and diverse methods. For all these reasons, the aim of this book is to bring out a general view on the biogeochemical cycles, the ecological imprints, the mathematical models and theories applicable to many situations.

\title{
How to reference
}

In order to correctly reference this scholarly work, feel free to copy and paste the following:

Jeffrey P. Blick (2012). Human Impacts on a Small Island Ecosystem: Lessons from the Lucayans of San Salvador, Bahamas for This Island Earth, The Functioning of Ecosystems, Prof. Mahamane Ali (Ed.), ISBN: 978-953-51-0573-2, InTech, Available from: http://www.intechopen.com/books/the-functioning-ofecosystems/human-impacts-on-a-small-island-ecosystem-lessons-from-the-lucayans-of-san-salvadorbahamas-for-th

\section{INTECH}

open science | open minds

\section{InTech Europe}

University Campus STeP Ri

Slavka Krautzeka 83/A

51000 Rijeka, Croatia

Phone: +385 (51) 770447

Fax: +385 (51) 686166

www.intechopen.com

\section{InTech China}

Unit 405, Office Block, Hotel Equatorial Shanghai

No.65, Yan An Road (West), Shanghai, 200040, China 中国上海市延安西路65号上海国际贵都大饭店办公楼 405 单元

Phone: +86-21-62489820

Fax: +86-21-62489821 
(C) 2012 The Author(s). Licensee IntechOpen. This is an open access article distributed under the terms of the Creative Commons Attribution 3.0 License, which permits unrestricted use, distribution, and reproduction in any medium, provided the original work is properly cited. 